\title{
Influence of red mud on soil microbial communities: application and comprehensive evaluation of the Biolog EcoPlate approach as a tool in soil microbiological studies
}

\author{
Viktória Feigl $^{1 *}$, Éva Ujaczki ${ }^{1}$, Emese Vaszita $^{1}$, Mónika Molnár $^{1}$ \\ ${ }^{1}$ Budapest University of Technology and Economics, Faculty of Chemical Technology and \\ Biotechnology, Department of Applied Biotechnology and Food Science \\ Address: 1111 Budapest, Müegyetem Rkp. 3, Hungary \\ * Correspondig author e-mail: vfeigl@mail.bme.hu, phone: +361-463-2347
}

\begin{abstract}
Red mud can be applied as soil ameliorant to acidic, sandy and micronutrient deficient soils. There are still knowledge gaps regarding the effects of red mud on the soil microbial community. The Biolog EcoPlate technique is a promising tool for community level physiological profiling. This study presents a detailed evaluation of Biolog EcoPlate data from two case studies. In experiment "A" red mud from Ajka (Hungary) was mixed into acidic sandy soil in soil microcosms at 5-50 w/w\%. In experiement "B" red mud soil mixture was mixed into low quality subsoil in a field experiment at 5-50 w/w\%. According to average well color development, substrate average well color development and substrate richness 5-20\% red mud increased the microbial activity of the acidic sandy soil over the short term, but the effect did not last for 10 months. Shannon diversity index showed that red mud at up to $20 \%$ did not change microbial diversity over the short term, but the diversity decreased by the $10^{\text {th }}$ month. $30-50 \%$ red mud had deteriorating effect on the soil microflora. 5-20\% red mud soil mixture in the low quality subsoil had a long lasting enhancing effect on the microbial community based on all Biolog EcoPlate parameters. However, 50\% red mud soil mixture caused a decrease in diversity and substrate richness. With the Biolog EcoPlate we were able to monitor the changes of the microbial community in red mud affected soils and to assess the amount of red mud and red mud soil mixture applicable for soil treatment in these cases.
\end{abstract}

\section{Highlights}

- Selected Biolog EcoPlate indices are applicable to assess the effect of red mud.

- Red mud at 5-20\% enhances the microbial activity of an acidic sandy soil.

- Microbial diversity is decreasing upon red mud addition over the long term.

- $10-20 \%$ red mud-soil mixture enhances microbial acitivity of degraded soil.

\section{Keywords}

Biolog EcoPlate, community-level physiological profiling, red mud, soil amendment, soil microbial community 


\section{Abbreviations}

AWCD: average well colour development

CLPP: community-level physiological profiling

E: Shannon evenness

$\mathrm{H}$ : Shannon diversity index

LQS: low quality subsoil

OD: optical density

RM: red mud

RMSM: red mud and soil mixture

S: acidic sandy soil

SAWCD: substrate average well color development

SR: substrate richness

\section{Introduction (Deleted sentences are not included in the text.)}

Microbial communities have an important role in many soil processes (e.g. organic matter formation and decomposition, respiration, nutrient cycling) (Condron et al., 2010, DelgadoBaquerizo et al., 2016, Schimel and Schaeffer, 2012, Schulz et al., 2013) and the delivery of essential soil ecosystem services (Jeffery et al., 2010, Van Der Heijden et al., 2008). In contrast to the physical and chemical properties of soil which change very slowly, biological properties are sensitive even to small environmental fluctuations (Nannipieri et al., 2003, Jezierska-Tys, 2008, Carbonell, 2009, Gryta et al., 2014). Some scientists realised that standard microbiological methods can be combined with a community approach in order to detect any possible structural and/or functional change of soil microbial population (Kelly et al., 1999; Larkin, 2003; Viti et al., 2006, Garau et al., 2007).

The Biolog MicroPlates developed in the late 1980s were 96-well Gram-negative (GN) plates containing carbon sources and a tetrazolium violet redox dye that turned purple if inoculated microorganisms extracted from the soil utilised these sources (Garland and Mills, 1991, Garland, 1997). Later, a new plate specifically designed for community analysis and microbial ecological studies was created, referred to as the EcoPlate. The EcoPlate contains three replicate wells of 31 of the most useful carbon sources for soil community-level physiological profiling (CLPP) of heterotrophic bacterial assemblages capable of being metabolically active and growing in plate conditions (Insam, 1997, Stefanowicz, 2006). According to Gryta et al., 2014 the Biolog EcoPlate method is more dedicated to compare functional diversity of microbial communities from contaminated and uncontaminated soils rather than to characterize microbial community, as applied by other authors (Preston-Mafham et al., 2002, Arias et al., 2005).

Monitoring the effect of soil additives Huang et al., 2017 found that the CLPP-based results on the activity and functional diversity of the soil microbial community were in accordance with the high-throughput sequencing results (16S rRNA and ITS rRNA gene-based approaches). In a comparative study using Biolog EcoPlate, 16S rRNA gene denaturing gradient gel electrophoresis (DGGE), or phospholipids fatty acid (PLFA) profiling analysis Xue 
et al., 2008 showed similar results in terms of the effect of land-use change on the soil microbial community structure.

CLPP yields a very large amount of data that may be difficult to interpret. Biolog-derived data for evaluation generally include: the Average Well Colour Development (AWCD) and the Shannon diversity index (H) (Stefanowicz, 2006, Frąc et al., 2012, Kenarova et al., 2014, Muñiz et al., 2014). AWCD is an indicator of the general potential metabolic activity of the microbial community, thus it is an index of the total bioactivity for the Biolog plates (Frąc et al., 2012, Kenarova et al., 2014). AWCD values can be subdivided into SAWCD (substrate average well color development) groups based on substrate guilds (carbon sources) of similar chemical nature, (e.g. amino acids, amines, carbohydrates, carboxylic acids, phenolyc compounds and polymers) to assess the potential of the soil microbial community to degrade these carbon sources (Zak et al., 1994, Kenarova et al., 2014, Sala et al., 2010). The Shannon diversity index $(\mathrm{H})$ is used to calculate the physiological diversity of bacterial communities (Kenarova et al., 2014). Microbial communities that are able to degrade more substrates or/and to degrade them with similar efficiency would have higher values of $\mathrm{H}$ compared to that part of the community which is not metabolically active and is not capable of growing in plate conditions (Muñiz et al., 2014). Some authors calculated also several additional Biolog EcoPlate derived parameters, such as substrate richness (SR) and Shannon evenness (E) (Gryta et al., 2014, Garau et al., 2007).

The Biolog EcoPlate technique has been increasingly used to assess the toxicological impacts of different pollutants (Preston-Mafham et al., 2002), such as heavy metals (Rusk et al., 2004; Kamitani et al., 2005, Niklinska et al., 2005, Boshoff et al., 2014), uranium (Kenarova et al., 2014) or hydrocarbon contamination (Bundy et al., 2004, Nagy et al., 2013) on soil microbial populations, or for estimating the impact of other stressing factors such as high salinity and high soil pH (Pankhurst et al., 2001), or heating (Pietikäinen et al., 2000).

Red mud (bauxite residue) is a by-product of the alumina industry, deriving from the digestion of crushed bauxite with caustic soda. Due to the combined presence of ferric, aluminium and tectosilicate-like compounds in red mud (Gadepalle et al., 2007), it is proved to be an effective amendment in reducing metal mobility in contaminated soils and stimulating microbial abundance, diversity and activity (Garau et al., 2007, 2011, Lombi et al., 2002, Gray et al., 2006, Bertocchi et al., 2006, Castaldi et al., 2009, Feigl et al., 2012, Sprocati et al., 2014).

Sandy soils, with little or no nutrient or water holding capacity could benefit from the uses of red mud as soil ameliorant (McPharlin et al., 1994, Barrow, 1982, Ujaczki et al., 2015, Ujaczki et al., 2016 a,b) due to the presence of sodalite in red mud, with an estimated cation exchange capacity (CEC) that exceeds the CEC of most natural clays. In addition, the alkaline nature of red mud can be used to raise the $\mathrm{pH}$ of organic or acidic soils (Summers et al., 1996, 2001, Snars et al., 2004), which tend to suffer from Al phytotoxicity (Alva et al., 2002). Additionally, due to red mud mineralogy (iron and aluminium oxides, hydroxides) it can increase the phosphorus retention of sandy soils adsorbing phosphate (Summers et al., 1993, Summers and Pech, 1997), thus reducing phosphate leaching and preventing eutrophication, and creating a phosphate pool that is available to plants and soil microorganisms. However, the alkalinity, the trace metal content and the naturally occurring radioactive material content of red mud may pose significant environmental risks (Akinci and Artir, 2008, Klauber et al., 
2011), therefore its careful application is recommended in soil (Ruyters et al., 2011, Ujaczki et al., 2015, 2016a, Mayes et al., 2016).

Despite the results showing that red mud can stimulate the recovery of the microbial abundance and activity in metal polluted soils (Lombi et al., 2002, Garau et al., 2007, 2011), in these studies the effect of red mud on the microbiological parameters was associated with the reduction of metal mobility. Therefore, further studies are needed to better understand the influence of red mud not only on polluted soils but also in improving soil quality, given the scarcity of published research on this topic. Recently Ujaczki et al., 2016a have studied the effect of red mud (RM) as acidic sandy soil (S) ameliorant. Similarily Ujaczki et al., 2016b have studied in a field trial the potential application of red mud-soil mixture (RMSM) as additive to the surface layer of a landfill cover system made from low quality subsoil (LQS). Both papers dealt with the complex effects assessment of RM and RMSM on the soil and determined the maxium allowable amount to be utilized as soil additive. However, these studies have not focused primarily on the effect of RM and RMSM on the soil microbial community with a comprehensive evaluation of the Biolog EcoPlate derived parameters but were rather limited only to the AWCD values calculated from Biolog data and to the physical, chemical and ecotoxicological effects.

The objectives of our study are to assess the applicability of the Biolog EcoPlate system for monitoring the effect of these amendments (RM and RMSM) on the structure and activity of microbial communities in a degraded soil, based on our previous two case studies (Ujaczki et al., 2016 a,b) and to select the most fitting Biolog EcoPlate derived evaluation indices to estimate the efficiency of the applied soil improvement technology with red mud from the point of view of the soil microbial community.

\section{Materials and methods}

In experiment "A" red mud (RM) from Ajka (red mud, sampled in February 2011, 4 months after the accident from the top of a flooded grassland) was added at 0, 5, 10, 20, 30, 40 and $50 \mathrm{w} / \mathrm{w} \%$ to an acidic sandy soil (S) (sandy texture $87 \mathrm{w} / \mathrm{w} \%$ sand) from Nyírlugos, Hungary in a microcosm experiment (Ujaczki et al., 2016a). The soil samples were placed into $2 \mathrm{~kg}$ pots, kept at room temperature and irrigated every 2 weeks. Soil samples were taken from the red mud treated and the untreated pots at the $3^{\text {rd }}, 5^{\text {th }}$ and $10^{\text {th }}$ month of the soil amelioration experiment.

In experiment " $\mathrm{B}$ " red mud and soil mixture (RMSM) from Ajka (originating from the red mud flooded area after removal of the RM flooded soil together with the overlain RM layer as remediation action after the accident) was added at $0,5,10,20,50$ and $100 \mathrm{w} / \mathrm{w} \%$ to a low quality subsoil (LQS) (clay loam) in a field experiment (Ujaczki et al., 2016b). The RMSM + LQS mixtures were used as surface layer of a landfill cover system in Gyál (Hungary). The size of each plot was $10 \mathrm{~m}^{2}$, RMSM was mixed into LQS down to $0.2 \mathrm{~m}$ depth and the plots were irrigated on dry days for $1 \mathrm{hr} /$ day. The plots were sampled during the $1^{\text {st }}, 5^{\text {th }}$ and $10^{\text {th }}$ month. The physico-chemical characteristics of the soils and amendments are summarized in Table 1, and the toxic metal and metalloid content is given in Table 2.

Both experiments were monitored by an integrated methodology (Gruiz et al., 2009) including physical, chemical, biological and direct contact ecotoxicological test methods (Gruiz et al., 2016). In this study we focus only on how the RM and RMSM amendments influence the 
substrate utilization of the microbial community (community level physiological profiling, CLPP) in the soil applying the BIOLOG EcoPlate method (Garland, 1997). The measurements were carried out as described by Nagy et al., 2013. $10 \mathrm{~g}$ soil was suspended in $90 \mathrm{ml} 0.85 \%$ sterile $\mathrm{NaCl}$ solution and shaken at $22{ }^{\circ} \mathrm{C}$ for 30 minutes at $150 \mathrm{rpm}$. After 10 minutes settling, $1 \mathrm{ml}$ supernatant was diluted in $9 \mathrm{ml} 0.85 \%$ sterile $\mathrm{NaCl}$ solution. $125 \mu 1$ of this suspension was pipetted into the microplate wells, and then incubated at $25^{\circ} \mathrm{C}$ in the dark. The absorbance was measured with DIALAB EL800 Microplate Reader at every 24 hours for 120 hours at $490 \mathrm{~nm}$ wavelength. The Biolog EcoPlate method usually measures optical density (OD) at $590 \mathrm{~nm}$ because the peak absorbance of the tetrazolium dye occurs at $590 \mathrm{~nm}$ (Garland, 1997, Muñiz et al., 2014, Garau et al., 2007). Nevertheless we used absorbance values at $490 \mathrm{~nm}$ because our microplate reader was equipped with 405, 450, 490 and $630 \mathrm{~nm}$ filters, but the optimal OD values were provided at $490 \mathrm{~nm}$ (Nagy et al., 2013). Others have also used different wavelengths for OD measurement (Zak et al., 1994, Boshoff et al., 2014). All measurements were done in three replicates as the 96 well system contains three times the 31 carbon sources and three times the control well (blank).

The OD values were subjected to data corrections prior to evaluation: $1^{\text {st }}$ substraction of the control well OD value (it contains only water for reading of the net absorption value) from each OD value of the substrate containing wells, $2^{\text {nd }}$ substraction of the initial OD value of each well (measured right after filling the wells with the soil suspension to eliminate the effect of soil particles on the optical density values) from the previously corrected OD values of each well. Negative values were set to 0 . The OD values for data evaluation were applied at $120 \mathrm{~h}$ since these represented the optimal range of OD readings (Frąc et al., 2012, Nagy et al., 2013, Gryta et al., 2014) and were best suited for comparison with other experiments with red mud as soil amendment (Garau et al., 2007, 2011). The endpoints calculated from the corrected data were the following: average well color development (AWCD), substrate average well color development (SAWCD), Shannon-index $(\mathrm{H})$, substrate richness (SR) and Shannon evenness (E).

Average well color development (AWCD) was calculated for all carbon sources with the following equation, according to Gryta et al., 2014: $A W C D=\sum O D_{i} / N$, where $O D_{i}$ is the corrected OD value of each substrate containing well and $\mathrm{N}$ is the number of substrates, in this case $\mathrm{N}=31$. To analyze AWCD of all carbon sources the substrates were grouped into six categories representing different substrate guilds according to Sala et al., 2010: amino acids (Larginine, L-asparagine, L-phenylalanine, L-serine, glycyl-L-glutamic acid, L-theronine,), amines (phenylethylamine, putrescine), carbohydrates (D-mannitol, glucose-1-phosphate, D,Lalpha-glycerol phosphate, beta-methyl-D-glucoside, D-galactonic acid-gamma-lactone, ierythritol, D-xylose, N-acetyl-D-glucosamine, D-cellobiose, alpha-D-lactose), carboxylic acids (D-glucosaminic acid, D-malic acid, itaconic acid, pyruvic acid methyl ester, Dgalactouronic acid, alpha-ketobutiryc acid, gamma-hydroxybutyric acid), phenolic compound (2-hydroxy benzoic acid, 4-hydroxy benzoic acid) and polymers (Tween 40, Tween 80, alphacyclodextrine, glycogen). Substrate average well color development (SAWCD) values for each substrate categories were calculated with the same equation: $\mathrm{SAWCD}=\sum \mathrm{OD} \mathrm{i} / \mathrm{N}$, where $\mathrm{OD}_{\mathrm{i}}$ is the corrected OD value of the substrates within the substrate category and $\mathrm{N}$ is the number of substrates in the category (Kenarova et al., 2014). 
The Shannon index $(\mathrm{H})$ resulted from $\mathrm{H}=-\Sigma \mathrm{P}_{\mathrm{i}} \ln \left(\mathrm{P}_{\mathrm{i}}\right)$, where $\mathrm{P}_{\mathrm{i}}=\mathrm{OD}_{\mathrm{i}} / \Sigma \mathrm{OD}_{\mathrm{i}}$, which is the proportional color development of the well over total color development of all wells of a plate (Garland and Mills, 1991, Tam et al., 2001, Muñiz et al., 2014). The number of substrates oxidized (substrate richness, SR) was calculated as the sum of the number of cells where $\mathrm{OD}_{\mathrm{i}}$ value reached 0.15 after $120 \mathrm{~h}$ (Garau et al., 2007). The Shannon evenness (E) was calculated from the Shannon index divided by the substrate richness as E=H/lnSR (Gryta et al., 2014).

We performed an analysis of variance (ANOVA) using StatSoft ${ }^{\circledR}$ Statistica 13.1 to calculate the significant effect of the amendments on various parameters. We established the level of significance at $p<0.05$. We used Fisher's Least Significant Difference (LSD) test or Newman Keul's test (when the criteria for the homogeneity of variances were not fulfilled) for the comparison of the effects of various amendment amounts. Values followed by the same letter indicate no significant differences in the calculated values at the level of $p<0.05$ at each sampling.

Pearson Product Moment Correlation Analysis was performed by StatSoft ${ }^{\circledR}$ Statistica 13.1 to examine the relationship between Biolog Ecoplate method variables and soil parameters (e.g. $\mathrm{pH}, \mathrm{EC}$, humus, $\mathrm{NH}_{4}{ }^{+}-\mathrm{N}, \mathrm{NO}_{3}{ }^{-}-\mathrm{N}$, Total $\mathrm{N}$ content and $\mathrm{RM} \%$ or RMSM\%). The level of significance was $\mathrm{p}<0.05$. Correlation was considered strong when the correlation coefficient $(\mathrm{r})$ was higher than 0.60 and very strong at $r>0.85$.

\section{Results}

\section{Experiment "A"}

\section{Average well color development}

$5 \%$ red mud (RM) addition to the acidic sandy soil (S) microcosms (experiment "A") significantly increased (by $126 \%$ and $23 \%$, respectively, from 0.13 ) the average well color development (AWCD) of the Biolog EcoPlates during the $3^{\text {rd }}$ and the $5^{\text {th }}$ months, but after the $10^{\text {th }}$ month no significant difference was observed (Figure 1). Generally, the AWCD was inhibited with the growing RM amount in the soil (except for the $5^{\text {th }}$ month in $40 \%$ RM amended soil). $10 \%$ and $20 \% \mathrm{RM}$ addition resulted in $83 \%$ and $67 \%$ increase, respectively, after the $3^{\text {rd }}$ month. However, this increase in the AWCD levels ceased by the $5^{\text {th }}$ and $10^{\text {th }}$ months showing a significant decrease compared to the untreated acidic sandy soil (S). $40 \%$ and $50 \% \mathrm{RM}$ resulted in 88-96\% inhibition of AWCD at all sampling times (except for the $5^{\text {th }}$ month in $40 \%$ RM). AWCD in the untreated control (S) increased with $221 \%$ between the $3^{\text {rd }}$ and $5^{\text {th }}$ months, but to a smaller extent (15-75\%) in other microcosms (except for the $40 \%$ and $50 \% \mathrm{RM}$ treatment). The results of the correlation analysis (Supplementary Table 1 and 2) showed that the AWCD values negatively correlated with the RM dose, the $\mathrm{pH}$ (only at months 5 and 10) and the electrical conductivity (EC), and positively with the nitrogen content $\left(\mathrm{NO}_{3}{ }^{-} \mathrm{-N}\right.$ and total $\mathrm{N}$ ) of the soil. Very strong negative correlation was found after 10 months for RM dose, $\mathrm{pH}$ and EC.

\section{Substrate average well color development}

After 3 months amino acids and carbohydrates SAWCD values increased significantly compared to the untreated soil (S) at up to 20\% RM amounts (Suppl Table 3). However, after the $5^{\text {th }}$ or $10^{\text {th }}$ months amino acids, amines, carbohydrates and phenolic compounds SAWCD decreased significantly for nearly all treatments compared to the untreated soil. Carboxylic acid 
and polymer utilization was significantly higher in the 5-10\% RM treated soil during the experiment as compared to the untreated soil. Correlation analysis (Suppl Table 2) indicated that the AWCD value correlated strongly with the amino acid and carbohydrate SAWCD among the substrate guilds.

Comparing the percent distribution of SAWCD for each treatment (Figure 2), one could see that with incremental RM doses the number of substrate groups utilizable by microbes is decreasing: the microbes utilized all six groups in the untreated acidic sandy soil (S), while only 3-5 groups were utilized in the RM treated soils after 10 months. At 50\% RM addition only amino acids, carboxylic acids and polymers were utilized. The SAWCD ratio by groups in the untreated acidic sandy soil (S) did not change during the experiment and the highest utilization was measured for carbohydrates (25-36\%), amino acids (21-33\%) and polymers (11-25\%). By the end of the 10 months at $5 \%$ and $10 \%$ RM dose polymers were utilized at most $(50 \%$ and $63 \%$, respectively), followed by carboxylic acids (24\% and $25 \%$, respectively). At $20 \%$ RM carboxylic acids (34\%), amino acids (27\%) and polymers (24\%) were utilized, while at 30\% RM the carboxylic acid utilization increased to $62 \%$ after 3 months, but the highest rate was found for amino acids (57\%) and carbohydrates (26\%) after 10 months. At 40\% and 50\% RM the carbohydrate utilization increased after 3 months to $69 \%$ and $100 \%$ respectively, but by the $10^{\text {th }}$ months it decreased to $34 \%$ at $40 \%$ RM rate (still the mostly utilized substrate group) and to $0 \%$ at $50 \% \mathrm{RM}$ rate. At $50 \% \mathrm{RM}$ the highest utilization rate was $43 \%$ for carboxylic acids and $37 \%$ for polymers after 10 months.

\section{Shannon indices and substrate richness}

Shannon diversity index $(\mathrm{H})$ did not change significantly after the $3^{\text {rd }}$ and $5^{\text {th }}$ months at low RM amounts (5-20\%), but it decreased significantly by 18-48\% compared to the untreated soil (S) at 30-50\% RM amount (Table 3). After 10 months $\mathrm{H}$ decreased significantly (29-52\%, to 1.5-2.2) in all treatments compared to the untreated soil (S), but there was no significant difference between the treatments.

Substrate richness (SR) showed similar pattern to H: it did not change significantly after the $3^{\text {rd }}$ and $5^{\text {th }}$ months (except for $20 \% \mathrm{RM}$ at the $5^{\text {th }}$ month) at low RM amounts (5-20\%), but it decreased significantly after the $10^{\text {th }}$ month from $12-15$ to $6-8$. At $30-50 \%$ RM amount significant decrease to $0-3$ was observed after 3 months and it remained at this level until the end of the experiment (except for $40 \% \mathrm{RM}$ at the $5^{\text {th }}$ month).

Shannon evenness (E) was maintained during the experiment at around 1.0-1.2 for the untreated acidic sandy soil (S) and the 5-20\% RM treated soils. However, E became significantly higher after the $3^{\text {rd }}$ and $5^{\text {th }}$ months at $30 \% \mathrm{RM}$ dose and after the $10^{\text {th }}$ month at $40 \% \mathrm{RM}$, and decreased to zero in the 50\% RM treated soil.

Shannon index $(\mathrm{H})$ and substrate richness (SR) strongly and very strongly correlated with AWCD (negative correlation) (Suppl Table 2), however there was no correlation between Shannon evenness (E) and AWCD. H correlated with RM dose and SR strongly correlated with all tested soil parameters (RM\%, pH, EC, $\mathrm{NO}_{3}-\mathrm{N}$ and Total N) (Suppl Table 4).

\section{Experiment "B"}

\section{Average well color development}


One month after the treatment at field conditions the red mud and soil mixture (RMSM) addition to the low quality subsoil (LQS) at 5-20\% RMSM dose decreased the AWCD by 27$36 \%$ (from 0.49 in LQS) in the Biolog EcoPlates (Figure 3) in experiment "B". As time went by the AWCD values for these treatments became higher than in LQS and the increase was significant after 10 months for all treatments (5\%, 10\% and 20\% RMSM). The best result was gained with 20\% RMSM addition achieving a 61\% increase reaching 0.97 AWCD value. The AWCD in the RMSM itself was significantly higher with 50-78\% than in LQS during the experiment (0.74-1.10). On the other hand, 50\% RMSM caused a significant increase during the $1^{\text {st }}$ and the $5^{\text {th }}$ month compared to LQS, but by the $10^{\text {th }}$ month at this RMSM dose $29 \%$ decrease was observed. AWCD positively correlated with RMSM dose, $\mathrm{pH}$, humus, $\mathrm{NO}_{3}{ }^{-} \mathrm{N}$ and total $\mathrm{N}$ content only over the short term ( $1^{\text {st }}$ and the $5^{\text {th }}$ months) (Suppl Table 5 and 6$)$.

\section{Substrate average well color development}

Substrate average well color development (SAWCD) generally increased with RMSM addition and with time irrespective of the substrate type (Suppl Table 7). Significant increase was observed at 50\% RMSM concentration in LQS and in the RMSM during the $1^{\text {st }}$ and the $5^{\text {th }}$ months for all substrates (except for amino acids, amines and carboxylic acids during the $1^{\text {st }}$ month) compared to LQS. This increase was mantained only in the RMSM for all the substrates (except for phenolic compounds) until the $10^{\text {th }}$ month. As such only the 50\% RMSM treatment resulted a significant decrease of SAWCD values for carbohydrates (34\%), carboxylic acids (19\%) and phenolic compounds (89\%) after 10 months compared to LQS. For all substrate groups (except for phenolic compounds where SAWCD of LQS was 0.58 ) 5\%, $10 \%$ and $20 \%$ RMSM addition resulted in a significant increase in SAWCD by the $10^{\text {th }}$ month (except for amines and polymers at 10\% RMSM). In this experiment all SAWCDs correlated with the AWCD value (Suppl Table 6).

The SAWCD percent distribution in case of each substrate group changed only slightly with RMSM treatment and the differences were also slight with time (Figure 4). The microflora of all treatments was able to utilize all 6 substrate groups. The utilization rates at the $10^{\text {th }}$ month were $14-18 \%$ for amino acids, $8-12 \%$ for amines (except for $18 \%$ at $5 \%$ RMSM), $19-26 \%$ for carbohydrates, 15-21\% for carboxylic acids, 9-12\% for phenolic compounds (except for 17\% in LQS and 3\% at 50\% RMSM) and 19-20\% for polymers (except for 31\% in 50\% RMSM).

\section{Shannon indices and substrate richness}

The Shannon diversity index $(\mathrm{H})$ decreased significantly, but to a small extent (up to $8 \%$ ) by all treatments and it was also lower in the RMSM after the $1^{\text {st }}$ month compared to LQS (Table 4). H decreased with time in the LQS, so the 5\% and 20\% RMSM treatment and the RMSM itself had a significantly higher $\mathrm{H}$ index after 10 months, but the $\mathrm{H}$ was lower than in the LQS at the $1^{\text {st }}$ month.

Substrate richness (SR) decreased with time in LQS from 30 to 22, but it remained the same (25-27) during the experiment in RMSM. 5\% RM treatment after the $1^{\text {st }}$ and $5^{\text {th }}$ months did not cause significant changes compared to LQS, but after the $10^{\text {th }}$ month it was siginificantly higher reaching the original level. The SR ranged between 20 and 25 in the $10 \%$ and 20\% RMSM treated LQS. Due to the 50\% RMSM treatment SR decreased by the $10^{\text {th }}$ month to 16 . 
Shannon evenness (E) did not show major changes due to the treatments as it ranged between 0.95 and 1.01 in all samples. At the end of the experiment $20 \%$ and $50 \%$ RMSM treatment resulted in significantly higher E compared to LQS.

Shannon diversity $(\mathrm{H})$ and substrate richness (SR) positively correlated with AWCD at the $5^{\text {th }}$ and $10^{\text {th }}$ months, while Shannon evenness (E) positively at the $1^{\text {st }}$ month (Suppl Table 6). H, SR and E did not correlate with the tested soil parameters at the $5^{\text {th }}$ and $10^{\text {th }}$ months (Suppl Table 8).

\section{Discussion}

Several case studies have demonstrated the applicability of red mud in soil amelioration and remediation, however, only a few have dealt with its effect on the soil biota, including the soil microorganisms (Lombi et al., 2002, Garau et al., 2007, 2011, Ujaczki et al., 2016a). In experiment "A" red mud (RM) at up to $20 \%$ had positive short term (3 months after treatment) effect on the microflora of an acidic sandy soil based on the AWCD values of the Biolog EcoPlate (Figure 1). The $\mathrm{pH}$, electrical conductivity (EC), salt content, $\mathrm{CaCO}_{3}$-content, plantavailable P-content and water holding capacity increased with incremental RM dose, while nitrogen-content (total $\mathrm{N}, \mathrm{NH}_{4}{ }^{+}-\mathrm{N}$ and $\mathrm{NO}_{3}{ }^{-}-\mathrm{N}$ ) and humus-content slightly decreased (Ujaczki et al., 2016a). EC and pH showed negative correlation, while nitrogen forms showed positive correlation with AWCD in our experiment (Suppl Table 2), thus the changes in the chemical composition of the soil do not explain the AWCD increase at low RM doses.

Other authors found similar intensification in the soil microbial activity when applying RM as chemical stabilizer in metal contaminated soil. Lombi et al., 2002 reported that 13 months after the application of $\mathrm{RM}$ at $2 \mathrm{w} / \mathrm{w} \%$ in two $\mathrm{Cd}, \mathrm{Pb}, \mathrm{Cu}, \mathrm{Ni}$ and $\mathrm{Zn}$ polluted soils, the microbial biomass in the soil was significantly greater in the treated soils in comparison with the untreated control. They explained this increase by the fact that RM reduced the toxicity of metals to microorganisms directly. In other studies, it was confirmed that beyond Biolog EcoPlate derived values other microbial parameters, such as fast-growing heterotrophic bacterial cell number, microbial abundance, the activity of selected enzymes (dehydrogenase, urease) were also improved after red mud treatment (Castaldi et al., 2009, Garau et al., 2007, 2011). Sprocati et al. 2014 explained the high functional diversity of the metabolic profile of toxic metal polluted soil gained after Viromine ${ }^{\mathrm{TM}}$ (a red mud derived product) treatment as related with the increase in $\mathrm{pH}$ caused by its the addition.

Garau et al., 2007 found that the microbial population from the $4 \mathrm{w} / \mathrm{w} \% \mathrm{RM}$ amended $\mathrm{Pb}, \mathrm{Cd}$ and $\mathrm{Zn}$ polluted sandy soil showed higher substrate richness measured by Biolog EcoPlate compared to the control soil while RM decreased significantly the solubility of $\mathrm{Pb}$, $\mathrm{Cd}$ and $\mathrm{Zn}$, which was likely responsible for the promotion of bacterial abundance. In addition based on the sequencing of the 16S rDNA gene the red mud treated soils contained mostly Gram negative bacteria affiliated to Ralstonia, Flavobacterium and Pedobacter genera, while Arthrobacter isolates were numerically the most abundant in the control soil. Garau et al., 2007 suggested that the AWCD value is mostly reflecting the potential metabolic activity of fastgrowing r-selected bacterial populations and that that Gram negative bacteria are mostly responsible for color development. The poor catabolic activity detected by Garau et al, 2007 in the control soil suggested the inability of Arthrobacter and Bacillus strains to oxidize the 
substrates in the Ecoplate rather than reflecting the actual catabolic versatility of the microbial communities. Although AWCD was lower in our study, the diversity was higher in the untreated control. so attention should be taken when comparing Biolog results in soils dominated by different microbial populations. These findings confirm that RM may have positive effects on the soil microflora, but the reasons for the microbial abundance increase as suggested by the above authors cannot be fully extrapolated to our study.

The AWCD increase in our study was not maintained during the 10 months of the experiment (Figure 1). We assume that the micro- and macronutrient input and the improvement in soil physical properties may have contributed to the enhanced microbial activity over the short term, but over the long term the microbes exhausted the available nutrients, nitrogen sources and the organic matter in the soil. However, this assumption was not supported by our chemical analytical data as the values were within the standard deviation range (Suppl Table 1), but a more detailed analysis of the available nutrient contents may reveal correlations. Garcia-Sánchez et al., 2015 observed a similar phenomenon when applying fly ash to metal contaminated soil provoking an increase in the bacterial communities at 30 and a decrease at 60 days of treatments. They explained the initial increase with the high input of easily available macro- and micronutrients, which probably promoted the growth and development of bacteria and fungi able to survive in extreme environments.

The immobilizing ability of RM (Gadepalle et al., 2007, Summers et al., 1993) may contribute to the nutrient scarcity over the long term. For example, Snars et al. (2002) reported that environmental stress, such as drying or the addition of microbial suppressants could mitigate the effect of the red mud in decreasing P availability. Red mud addition also may have caused a stress to microbes enhancing their metabolic activity, thus the resources exhausted faster than in stress free soils. Furthermore, the experimental conditions, such as a relatively small amount, incubation at room temperature and irrigation at regular intervals may also contribute to a decrease in microbial activity. Otherwise the AWCD values in the acidic sandy soil were small $(0.13$ after $120 \mathrm{~h})$, which indicates an originally low microflora activity in the acidic sandy soil (S), typical for degraded sandy soils (Garau et al., 2011).

Among the Biolog EcoPlate derived values only AWCD and SAWCD reflected the intensified microbial activity upon low RM doses over the short term. Amino acid and carbohydrate utilization were strongly correlated with AWCD and in case of these substrates the highest decrease was observed with time. Most of the carbohydrates are intermediates of soil organic matter degradation which explains the high affinity of bacteria to them (Kenarova et al., 2014). However, the utilization of some substrate groups (carboxylic acids and polymers with the highest utilization percentage) was maintained at a higher level in the treated soils (at up to $20 \% \mathrm{RM}$ and $10 \% \mathrm{RM}$, respectively) than in the untreated acidic sandy soil (S) over the long term, suggesting that RM addition created a more favorable environment for certain microbial groups in the soil to utilize specific substrates (Garau et al., 2011). At 30-50\% RM dose all values clearly indicated deteriorating effect on the microbial activity of the acidic sandy soil. The higher the RM amount added to the soil the lower the bacterial diversity in soil. At $30-50 \%$ RM does substrate richness was 0 or 1 , which means that only some species were able to remain metabolically active upon the great RM load in soil. As a consequence, we established the maximum RM dose that was still beneficial for the microbial community of the treated soil at $20 \% \mathrm{RM}$, although Ujaczki et al., 2016a found that toxic metal content (As, $\mathrm{Cr}$ and $\mathrm{Ni}$ ), $\mathrm{Na}$ 
content and toxicity input from red mud is tolerable by the acidic sandy soil ecosystem (based on ecotoxicity testing) only at up to $5 \% \mathrm{RM}$, therefore higher $\mathrm{RM}$ amounts are not recommended to be mixed into the soil. According to the AWCD values we also found that 5\% RM was the maximum dose maintaining its positive effect by the $5^{\text {th }}$ month. According to Somlai et al., 2008 Hungarian red mud contains $347 \mathrm{~Bq} / \mathrm{kg}^{226} \mathrm{Ra}, 283 \mathrm{~Bq} / \mathrm{kg}{ }^{232} \mathrm{Th}$ and $48 \mathrm{~Bq} / \mathrm{kg}$

${ }^{40} \mathrm{~K}$ and it can be applied in brick production as coloring agent at up to $15 \%$, so $5 \% \mathrm{RM}$ in soil could be acceptable.

Modeling the effects of the RM spill in Ajka Ujaczki et al., 2015 found that the aerobic heterotrophic cell counts (CFU) increased upon max. 40\% RM dose into the Ajka soil 2 months after addition. However, the elevated CFU was preserved only at 5\% RM dose until the $8^{\text {th }}$ month. Based on chemical, biological and ecotoxicological results Ujaczki et al., 2015 concluded that RM could be mixed at up to $5 \%$ into the soil without any mid-term adverse effect on the Ajka soil as natural habitat. This finding substantiated the recommended remediation option in the area: excavation of the RM flooded soil together with the overlain RM layer and storing of the excavated red mud and soil mixture (RMSM) in Ajka behind the red mud storage area. Rékási et al., 2013 showed similar results in a soil column experiment using $10 \mathrm{~cm}$ Ajka RM overlaying soil from Ajka: the CFU increased in the overlain soil until the $2^{\text {nd }}$ month, but it decreased by the $4^{\text {th }}$ month. Klebercz et al., 2012 measured $10-100$ times elevation of CFU in the contaminated sediment of the rivers affected by the Ajka RM spill compared to reference samples. All the above cases showed a significant increase in the plate cultivable microbes upon RM addition.

Mixing RMSM into LQS in experiment "B" at up to $20 \%$ increased the AWCD values after 10 months (Figure 3). Furthermore, AWCD values of RMSM were 10 times higher than of the acidic sandy soil in experiment " $A$ " and 2 times higher than of the LQS, confirming that CLPP is very sensitive to the soil type and texture (Rutgers et al., 2016). Thus RMSM contained an active and functioning microflora despite the red mud in it (estimated between $5-10 \mathrm{w} / \mathrm{w} \%$ based on sodium and toxic metal content). The positive effect of RMSM treatment on AWCD, SAWCD and SR in this experiment lasted during the monitored 10 months. 50\% RMSM dose was too high for the microbial community of the LQS, decreasing the AWCD values after 10 months. According to metal analysis and ecotoxicological results Ujaczki et al., 2016b recommended 20\% RMSM dose to be added to LQS. This dose was supported also by the Biolog EcoPlate results.

To assess the positive effects of similar soil amendments on the microflora of deteriorated soils we recommend calculation of the AWCD and SAWCD values, to assess the negative effects the AWCD, SAWCD, H and SR can be suggested. The utilization patterns of substrate groups could be a future research area aiming to find relations with the ecosystem functioning and functional diversity.

\section{Conclusions}

In this study the Biolog EcoPlate derived evaluation parameters were applied to investigate both the positive and the negative effects of red mud on the soil microflora in two soil amelioration case studies. In experiment "A" AWCD and SAWCD values indicated that $\mathrm{RM}$ addition at up to $20 \%$ increased the activity of the microflora in the acidic sandy soil during 
the short term (5 months) and was significantly not different in diversity from the untreated sandy soil (based on Shannon diversity indices), but this enhancing effect was not lasting and bacterial diversity became significantly lower. The addition of higher RM (30-50\%) doses should be avoided due to their deteriorating effects on the soil microflora indicated by all calculated indices. Although RM at up to $20 \%$ may be beneficial for the soil microflora, when $\mathrm{RM}$ is applied as soil ameliorant toxicity should also be tested and based on previous studies $5 \% \mathrm{RM}$ amount should not be exceeded. RMSM addition to LQS (experiment "B") at up to $20 \%$ was beneficial for the microbial activity based on AWCD results and the effect lasted until the end of the monitored 10 months as opposed to the short term effect of RM in experiment "A". This result was in agreement with the previous ecotoxicological results, so RMSM is suggested to be applied at up to 20\%. In turn 50\% RMSM addition decreased the microbial activity (AWCD and SAWCD values) and the diversity (based on $\mathrm{H}$ ), so the application of higher amounts should be avoided. Overall, the two case studies showed us that detailed analysis of the Biolog EcoPlate data provides a more thorough picture about the microbial activity and diversity of the soil microflora on a case by case basis.

\section{Acknowledgement}

The authors are thankful for the financial support of the National Research, Development and Innovation Office (OTKA PD 115871 and 121172; TECH_09-A4-2009-0129), the New Hungary Development Plan (TÁMOP-4.2.1/B-09/1/KMR-2010-0002), the Hungarian State, the European Union and the co-finance of the European Social Fund (TÁMOP 4.2.4.A-1 project). The authors are thankful for the Institute for Soil Sciences and Agricultural Chemistry, Centre for Agricultural Research, Hungarian Academy of Sciences for the soil chemical analysis.

\section{References}

Akinci A, Artir, R. Characterization of trace elements and radionuclides and their risk assessment in red mud. Mater Charact 2008;59(4):417-421.

Alva AK, Huang B, Paramasivam S, Sajwan KS. Evaluation of root growth limiting factors in spodic horizons of Spodosols. J Plant Nutr 2002;25(9):2001-2014.

Arias ME, Gonzalez-Perez JA, Gonzalez-Vila FJ, Ball AS. Soil health - a new challenge for microbiologists and chemists. Int Microbiology 2005;8:13-21.

Barrow NJ. Possibility of using caustic residue from bauxite for improving the chemical and physical properties of sandy soils. Aust J Agric Res, 1982;33:275-285.

Bertocchi AF, Ghiani M, Peretti R, Zucca A. Red mud and fly ash for remediation of mine sites contaminated with As, Cd, Cu, Pb and Zn. J Hazard Mater 2006;134:112-119.

Boshoff M, DeJonge M, Dardenne F, Blust R, Bervoets L. The impact of metal pollution on soil faunal and microbial activity in two grassland ecosystems. Environ Res 2014;134:169-180. 
Bundy JG, Paton GI, Campbell CD. Combined microbial community level and single species biosensor responses to monitor recovery of oil polluted soil. Soil Biol Biochem 2004;36:11491159.

Carbonell G, Gomez J, Babin M, Fernandez C, Alonso E, Tarazona J. Sewage sludge applied to agricultural soil: Ecotoxicological effects on representative soil organisms. Ecotox Environ Safe 2009;72:1309-1319.

Castaldi P, Melis P, Silvetti M, Deiana S, Garau G. Influence of pea and wheat growth on Pb, $\mathrm{Cd}$, and $\mathrm{Zn}$ mobility and soil biological status in a polluted amended soil. Geoderma 2009;151:241-248.

Condron L, Stark C, O'Callaghan M, Clinton P, Huang Z. The Role of Microbial Communities in the Formation and Decomposition of Soil Organic Matter. In: Dixon GR, Tilston EL, editors. Soil Microbiology and Sustainable Crop Production, Springer Science+Business Media B.V; 2010, p. 81-118.

Delgado-Baquerizo M, Grinyer J, Reich PB, Singh BK. Relative importance of soil properties and microbial community for soil functionality: insights from a microbial swap experiment. Funct Ecol 2016;30:1862-1873.

Feigl V, Anton A, Uzinger N, Gruiz K. Red mud as a chemical stabilizer for soil contaminated with toxic metals. Water Air Soil Poll 2012;223(3):1237-1247.

Frąc M, Oszust K, Lipiec J. Community Level Physiological Profiles (CLPP), Characterization and microbial activity of soil amended with dairy sewage sludge. Sensors 2012;12:3253-3268.

Gadepalle VP, Ouki SK, Van Herwijnen, Hutchings T. Immobilization of heavy metals in soil using natural waste materials for vegetation establishment on contaminated sites. Soil Sediment Contam 2007;16:233-251.

Garau G, Castaldi P, Santona L, Deiana P, Melis P. Influence of red mud, zeolite and lime on heavy metal immobilization, culturable heterotrophic microbial populations and enzyme activities in a contaminated soil. Geoderma 2007;142:47-57.

Garau G, Silvetti M, Deiana S, Deiana P, Castaldi P. Long-term influence of red mud on As mobility and soil physico-chemical and microbial parameters in a polluted sub-acidic soil. $\mathbf{J}$ Hazard Mater 2011;185(2-3):1241-8.

Garcia-Sánchez M, Garcia-Romera I, Cajthaml T, Tlustoŝ P, Száková J. Changes in soil microbial community functionality and structure in a metal-polluted site: The effect of digestate and fly ash applications. J Environ Manage 2015;162:63-73.

Garland JL, Mills AL. Classification and characterization of heterotrophic microbial communities on the basis of patterns of community-level sole-carbon-source utilization. Appl Environ Microbiol 1991;57(8):2351-2359.

Garland JL. Analysis and interpretation of community-level physiological profiles in microbial ecology. FEMS Microbiol Ecol 1997;24:289-300. 
Gray CW, Dunham SJ, Dennis PG, Zhao FJ, McGrath SP. Field evaluation of in situ remediation of a heavy metal contaminated soil using lime and red-mud. Environ Pollut 2006;142:530-539.

Gruiz K, Fekete-Kertész I, Kunglné Nagy Zs, Hajdu C, Feigl V, Vaszita E, Molnár M. Direct toxicity assessment - methods, evaluation, interpretation. Sci Total Environ, 2016;563-564: 803-812.

Gruiz K, Molnár M, Feigl V. Measuring adverse effects of contaminated soil using interactive and dynamic test methods. Land Contam Reclam 2009;17:443-459.

Gryta A, Frąc M, Oszust K. The Application of the Biolog EcoPlate Approach in Ecotoxicological Evaluation of Dairy Sewage Sludge. Appl Biochem Biotechnol 2014;174:1434-1443.

Huang N, Wang W, Yao Y, Zhu F, Wang W, Chang X. The influence of different concentrations of bio-organic fertilizer on cucumber Fusarium wilt and soil microflora alterations. PLoS ONE 2017;12(2):e0171490.

Insam H. A new set of substrates proposed for community characterization in environmental samples. In: Insam H, Rangger A, editors. Microbial Communities Functional versus structural approaches, Heidelberg: Springer Verlag. Springer; 1997, p. 260-261.

Jeffery S, Gardi C., Jones A, Montanarella L, Marmo L, Miko L. et al. European Atlas of Soil Biodiversity. Luxembourg: Publications Office of the European Union; 2010.

Jezierska-Tys S, Frąc M. Microbiological indices of soil quality fertilized with dairy sewage sludge. Int Agrophys 2008;22:215-219.

Kamitani T, Oba H, Kaneko N. Microbial biomass and tolerance of microbial community on an aged heavy metal polluted floodplain in Japan. Water Air Soil Pollut 2006;172:185-200.

Kandeler E, Kampichler C, Horak O. Influence of heavy metals on the functional diversity of soil microbial communities. Biol Fertil Soils 1996;23(3):299.

Kelly JJ, Häggblom M, Tate RL. Changes in soil microbial communities over time resulting from one time application of zinc: a laboratory microcosm study. Soil Biol Biochem 1999;31:1455-1465.

Kenarova A, Radeva G, Traykov I, Boteva S. Community level physiological profiles of bacterial communities inhabiting uranium mining impacted sites, Ecotoxicol. Environ. Saf 2014;100:226-232.

Klauber C, Gräfe M, Power G. Bauxite residue issues: II. Options for residue utilization. Hydrometallurgy 2011;108:11-32.

Klebercz O, Mayes WM, Anton ÁD, Feigl V, Jarvis Á., Gruiz K. Ecotoxicity of fluvial sediments downstream of the Ajka red mud spill, Hungary. J Environ Monit 2012;14 (8): 20632071. 
Larkin RP. Characterization of soil microbial communities under different potato cropping systems by microbial population dynamics, substrate utilization, and fatty acid profiles. Soil Biol Biochem 2003;35:1451-1466.

Lombi E, Zhao FJ, Zhang G, Sun B, Fitz W, Zhang H, McGrath SP. In situ fixation of metals in soils using bauxite residue: chemical assessment. Environ Pollut 2002;118:435-443.

Mayes WM, Burke IT, Gomes HI, Anton AD, Molnár M, Feigl V, Ujaczki É. Advances in understanding environmental risks of red mud after the Ajka spill, Hungary. J Sustain Metall 2016;2:332-343.

McPharlin IR, Jeffrey RC, Toussaint LF, Cooper MB. Phosphorus, nitrogen and radionuclide retention and leaching from a Joel Sand amended with red mud/ gypsum. Commun Soil Sci Plan 1994;25(17-18):2925-2944.

Muñiz S, Lacarta J, Pata MP, Jiménez JJ, Navarro E (2014) Analysis of the Diversity of Substrate Utilisation of Soil Bacteria Exposed to Cd and Earthworm Activity Using Generalised Additive Models. PLoS ONE 9(1): e85057.

Nagy ZsM, Gruiz K, Molnár M, Fenyvesi É. Comparative evaluation of microbial and chemical methods for assessing 4-chlorophenol biodegradation in soil. Period Polytech-Chem 2013;57/1-2:25-35.

Nannipieri P, Ascher J, Ceccherini MT, Landi L, Pietramellara G, Renella G. Microbial diversity and soil functions, Eur J Soil Sci 2003;54:655-670.

Niklinska M, Chodak M, Laskowski R. Characterization of the forest humus microbial community in a heavy metal polluted area. Soil Biol Biochem 2005;37:2185-2194.

Pankhurst CE, Yu S, Hawke BG, Harch BD. Capacity of fatty acid profiles and substrate utilization patters to describe differences in soil microbial communities associated with increased salinity or alkalinity at three locations in South Australia. Biol Fertil Soils 2001;33:204-217.

Pietikäinen J, Hiukka R, Fritze H. Does short-term heating of forest humus change its properties as a substrate for microbes? Soil Biol Biochem 2000;32: 277-288.

Preston-Mafham J, Boddy L, Randerson PF. Analysis of microbial community functional diversity using sole-carbon-source utilisation profiles: a critique. FEMS Microbiol Ecol 2002;42:1-14.

Rékási M, Feigl V, Uzinger N, Gruiz K, Makó A, Anton A. The effects of leaching from alkaline red mud on soil biota: modelling the conditions after the Hungarian red mud disaster. Chem Ecol 2013;29(8):709-723.

Rusk JA, Hamon RE, Stevens DP, McLaughlin MJ. Adaptation of soil biological nitrification to heavy metals. Environ Sci Technol 2004;38:3092-3097.

Rutgers M, Schouten AJ, Bloem J, Van Eekeren N, De Goede RGM, Jagersop A et al. Biological measurements in a nationwide soil monitoring network. Eur J Soil Sci 2009;60: 820832. 
Ruyters S, Mertens J, Vassilieva E, Dehandschutter B, Poffijn A, Smolders E. The red mud accident in Ajka (Hungary): plant toxicity and trace metal bioavailability in red mud contaminated soil. Environ Sci Technol 2011;45:1616-1622.

Sala MM, Boras JA, Vaque D. The impact of ice melting on bacterioplankton in the Arctic Ocean, Polar Biol 2010;33:1683-1694.

Schimel JP, Schaeffer SM. Microbial control over carbon cycling in soil. Front Microbio 2012;3:348.

Schulz S, Brankatschk R., Dumig A, Kogel-Knabner I, Schloter M, Zeyer J. The role of microorganisms at different stages of ecosystem development for soil formation. Biogeosciences 2013;10:3983-3996.

Schutter M, Dick R. Shifts in substrate utilization potential and structure of soil microbial communities in response to carbon substrates. Soil Biol Biochem 2001;33:1481.

Snars K, Gilkes R, Hughes J. Effect of bauxite residue (red mud) on the availability of phosphorous in very sandy soils. Conference proceedings of the $17^{\text {th }}$ WCCS, 17-21 August 2002, Thailand. Paper 1808.

Snars KE, Gilkes R, Wong M. The liming effect of bauxite processing residue (red mud) on sandy soils. Aust J Soil Res 2004;42:321-328.

Somlai J, Jobbágy V, Kovács J, Tarján S, Kovács T. Radiological aspects of the usability of red mud as building material additive. J Haz Mat 2008;150:541-545.

Sprocati AR, Alisi C, Pinto V, Montereali MR, Marconi P, Tasso F, Turnau K, De Giudici, Goralska K, Bevilacqua M, Marini F, Cremisini C. Assessment of the applicability of a "toolbox" designed for microbially assisted phytoremediation: the case study at Ingurtosu mining site (Italy). Environ Sci Pollut Res 2014; 21:6939-6951.

Stefanowicz AM. The Biolog Plates Technique as a Tool in Ecological Studies of Microbial Communities, Polish J of Environ Stud 2006;15(5): 669-676.

Summers RN and Pech JD. Nutrient and metal content of water, sediment and soils amended with bauxite residue in the catchment of the Peel Inlet and Harvey Estuary, Western Australia Agriculture. Ecosyst Environ 1997;64(3):219-232.

Summers RN, Guise N, Smirk D, Summers K. Bauxite residue (red mud) improves pasture growth on sandy soils in Western Australia. Aust J Soil Res 1996;34:569-581.

Summers RN, Guise NR, Smirk DD. Bauxite residue (Red Mud) increases phosphorus retention in sandy soil catchment inWestern Australia. Fertil Res 1993;34:85-94.

Summers, RN, Bolland M, Clarke M. Effect of application of bauxite residue (red mud) to very sandy soils on subterranean clover yield and P response. Aust Soil Res 2001;39(5):979-990.

Tam L, Derry AM, Kevan PG, Trevors JT. Functional diversity and community structure of microorganisms in rhizosphere and non-rhizosphere, Canadian arctic soils. Biodivers Conserv 2001;10:1933-1947. 
Ujaczki É, Feigl, Farkas É, Vaszita E, Gruiz K, Molnár M. Red mud as acidic sandy soil ameliorant: a microcosm incubation study. J Chem Technol Biotechnol 2016a;91:1596-1606.

Ujaczki É, Feigl V, Molnár M, Vaszita E, Uzinger N, Erdélyi A et al. The potential application of red mud and soil mixture as additive to the surface layer of a landfill cover system, J Environ Sci 2016b;44:189-196.

Ujaczki E, Klebercz O, Feigl V, Molnar M, Magyar A, Uzinger N et al. Environmental toxicity assessment of the spilled Ajka red mud in soil microcosms for its potential utilisation as soil ameliorant. Period Polytech Chem 2015;59:253-261.

Van Der Heijden MGA, Bardgett RD, Van Straalen NM. The unseen majority: soil microbes as drivers of plant diversity and productivity in terrestrial ecosystems. Ecol Lett, 2008;11:296310 .

Viti C, Mini A, Ranalli G, Lustrato G, Giovannetti L. Response of microbial communities to different doses of chromate in soil microcosms. Appl Soil Ecol 2006;34:125-139.

Xue D, Yao HY, Ge DY, Huang CY. Soil microbial community structure in diverse land use systems: a comparative study using Biolog, DGGE, and PLFA Analyses. Pedosphere 2008;18(5):653-663.

Zak JC, Willig MR, Moorhead DL, Wildman HG. Functional diversity of microbial communities: a quantitative approach. Soil Biol Biochem 1994;26:1101-1108. 
List of tables:

Table 1. Physico-chemical properties of the soils and amendments

\begin{tabular}{c|ccccccccccc} 
& $\begin{array}{c}\mathrm{pH} \\
\left(\mathrm{H}_{2} \mathrm{O}\right)\end{array}$ & $\begin{array}{c}\mathrm{EC} \\
(\mu \mathrm{S} / \mathrm{cm})\end{array}$ & $\begin{array}{c}\mathrm{Salts} \\
(\%)\end{array}$ & $\begin{array}{c}\mathrm{CaCO}_{3} \\
(\mathrm{w} / \mathrm{w} \%)\end{array}$ & $\mathrm{K}_{(\mathrm{A})}$ & $\begin{array}{c}\mathrm{Humus} \\
(\%)\end{array}$ & $\begin{array}{c}\mathrm{NH}_{4}{ }^{+}-\mathrm{N} \\
(\mathrm{mg} / \mathrm{kg})\end{array}$ & $\begin{array}{c}\mathrm{NO}_{3}-\mathrm{N} \\
(\mathrm{mg} / \mathrm{kg})\end{array}$ & $\begin{array}{c}\text { Total N } \\
(\mathrm{w} / \mathrm{w} \%)\end{array}$ & $\begin{array}{c}\mathrm{Al}-\mathrm{K}_{2} \mathrm{O} \\
(\mathrm{mg} / \mathrm{kg})\end{array}$ & $\begin{array}{c}\mathrm{Al}^{-\mathrm{P}_{2} \mathrm{O}_{5}} \\
(\mathrm{mg} / \mathrm{kg})\end{array}$ \\
\hline $\mathrm{S}$ & 5.7 & 496 & 0.1 & 0.3 & 26 & 0.6 & 35.1 & 96.4 & 0.04 & 240 & 140 \\
LQS & 8.5 & 1161 & 0.2 & 17.1 & 44 & 1.2 & 8.4 & 2.0 & 0.10 & 214 & 51 \\
RMSM & 8.3 & 1567 & 0.2 & 13.7 & 56 & 3.2 & 13.3 & 65.5 & 0.20 & 308 & 248 \\
$\mathrm{RM}$ & 10.5 & 8760 & 1.6 & 59 & 59 & 0.4 & 3.2 & 3.2 & 0.03 & 418 & 660
\end{tabular}

pH and EC was determined in a 1:2.5 soil:water suspension according to the Hungarian Standard (HS) 214702:1981. Water soluble salts: HS 08-0012-3:1979. $\mathrm{CaCO}_{3}$ : $\mathrm{HS}$ 08-0206-2:1978. $\mathrm{K}_{(\mathrm{A})}$ is texture based on Arany number: HS 21470-51:1983. Humus: HS 21470-52:1983, humus $(\%)=1.724^{*}$ soil organic C (\%). Total N content: HS 08-0012-10:1987. $\mathrm{NH}_{4}{ }^{+}-\mathrm{N}, \mathrm{NO}_{3}{ }^{-} \mathrm{N}, \mathrm{Al}-\mathrm{K}_{2} \mathrm{O}$ and Al- $\mathrm{P}_{2} \mathrm{O}_{5}$ : ammonium-lactate extractable, HS 20135:1999. 
Table 2. Toxic metal and metalloid content of the soils and amendments

\begin{tabular}{c|cccccc}
$\begin{array}{c}\text { Total metal } \\
\text { content } \\
(\mathrm{mg} / \mathrm{kg})\end{array}$ & $\mathrm{S}$ & LQS & RMSM & RM & HLV soil & $\begin{array}{c}\text { HLV } \\
\text { sewage } \\
\text { sludge }\end{array}$ \\
\hline $\mathrm{As}$ & $4.2 \pm 0.5$ & $11.3 \pm 1.2$ & $19.5 \pm 1.7$ & $32.3 \pm 0.1$ & 15 & 75 \\
$\mathrm{Cd}$ & $0.1 \pm 0.01$ & $0.1 \pm 0.04$ & $0.6 \pm 0.1$ & $1.2 \pm 0.01$ & 1 & 10 \\
$\mathrm{Co}$ & $4.3 \pm 0.2$ & $11.9 \pm 1.1$ & $23.4 \pm 2.0$ & $27.7 \pm 0.3$ & 30 & 50 \\
$\mathrm{Cr}$ & $15.9 \pm 2.9$ & $45.4 \pm 2.9$ & $69.6 \pm 2.2$ & $464 \pm 39$ & 75 & 1000 \\
$\mathrm{Cu}$ & $10.7 \pm 3.4$ & $22.5 \pm 0.3$ & $18.0 \pm 0.8$ & $16.6 \pm 1.5$ & 75 & 1000 \\
$\mathrm{Hg}$ & $<\mathrm{DL}$ & $<\mathrm{DL}$ & $<\mathrm{DL}$ & $0.9 \pm 0.1$ & 0.5 & 10 \\
$\mathrm{Mo}$ & $1.50 \pm 0.1$ & $0.30 \pm 0.1$ & $2.31 \pm 0.2$ & $4.1 \pm 0.9$ & 7 & 20 \\
$\mathrm{Ni}$ & $8.3 \pm 2.3$ & $32.0 \pm 0.6$ & $43.5 \pm 1.9$ & $199 \pm 7.8$ & 40 & 200 \\
$\mathrm{Zn}$ & $26.0 \pm 1.5$ & $75.5 \pm 5.8$ & $54.9 \pm 3.7$ & $45.6 \pm 5.9$ & 200 & 2500
\end{tabular}

Total metal content: aqua regia extraction, ICP-AES, HS 21470-50:2006. $<$ DL below detection limit, $\mathrm{DL}_{(\mathrm{Hg})}$ : 0.03 $\mathrm{mg} \mathrm{kg}^{-1}$. Hungarian Limit Value (HLV) for soil is based on KvVM-EüM-FVM Joint Decree No. 6/2009. HLV for sewage sludge from waste water treatment for agricultural applications is based on Government Decree No. $50 / 2001$. 
Table 3. Shannon diversity index (H), substrate richness (SR) and Shannon evenness (E) at $120 \mathrm{~h}$ during experiment " $\mathrm{A}$ "

\begin{tabular}{l|ccc|ccc|ccc} 
& \multicolumn{3}{|c|}{ Shannon diversity index $(\mathrm{H})$} & \multicolumn{3}{|c|}{ Substrate richness (SR) } & \multicolumn{3}{|c}{ Shannon evenness (E) } \\
Months & 3 & 5 & 10 & 3 & 5 & 10 & 3 & 5 & 10 \\
\hline S & $2.90^{\mathrm{a}}$ & $2.64^{\mathrm{a}}$ & $3.11^{\mathrm{a}}$ & $12.5^{\mathrm{a}}$ & $15.0^{\mathrm{a}}$ & $15.0^{\mathrm{a}}$ & $1.15^{\mathrm{a}}$ & $0.99^{\mathrm{a}}$ & $1.16^{\mathrm{a}}$ \\
$\mathrm{S}+5 \% \mathrm{RM}$ & $2.69^{\mathrm{a}}$ & $2.75^{\mathrm{a}}$ & $2.19^{\mathrm{b}}$ & $12.5^{\mathrm{a}}$ & $15.5^{\mathrm{a}}$ & $8.0^{\mathrm{b}}$ & $1.05^{\mathrm{a}}$ & $1.00^{\mathrm{a}}$ & $1.33^{\mathrm{a}}$ \\
$\mathrm{S}+10 \% \mathrm{RM}$ & $2.38^{\mathrm{ab}}$ & $2.66^{\mathrm{a}}$ & $2.17^{\mathrm{b}}$ & $12.5^{\mathrm{a}}$ & $14.5^{\mathrm{a}}$ & $6.0^{\mathrm{b}}$ & $0.98^{\mathrm{a}}$ & $0.99^{\mathrm{a}}$ & $1.21^{\mathrm{a}}$ \\
S+20\% RM & $2.60^{\mathrm{ab}}$ & $2.60^{\mathrm{a}}$ & $1.85^{\mathrm{b}}$ & $12.0^{\mathrm{a}}$ & $10.0^{\mathrm{b}}$ & $6.5^{\mathrm{b}}$ & $1.08^{\mathrm{a}}$ & $1.02^{\mathrm{a}}$ & $1.17^{\mathrm{a}}$ \\
S+30\% RM & $2.06^{\mathrm{b}}$ & $1.63^{\mathrm{b}}$ & $1.48^{\mathrm{b}}$ & $3.0^{\mathrm{b}}$ & $3.5^{\mathrm{c}}$ & $1.5^{\mathrm{c}}$ & $1.88^{\mathrm{b}}$ & $1.30^{\mathrm{b}}$ & $0.00^{\mathrm{b}}$ \\
S+40\% RM & $2.14^{\mathrm{b}}$ & $2.17^{\mathrm{c}}$ & $1.96^{\mathrm{b}}$ & $0.0^{\mathrm{c}}$ & $8.0^{\mathrm{d}}$ & $2.5^{\mathrm{c}}$ & $0.00^{\mathrm{c}}$ & $1.01^{\mathrm{a}}$ & $2.50^{\mathrm{c}}$ \\
S+50\% RM & $1.98^{\mathrm{b}}$ & $1.70^{\mathrm{b}}$ & $1.81^{\mathrm{b}}$ & $0.0^{\mathrm{c}}$ & $1.0^{\mathrm{e}}$ & $1.5^{\mathrm{c}}$ & $0.00^{\mathrm{c}}$ & $0.00^{\mathrm{c}}$ & $0.00^{\mathrm{b}}$
\end{tabular}


Table 4. Shannon diversity index $(\mathrm{H})$, substrate richness (SR) and Shannon evenness (E) at $120 \mathrm{~h}$ during experiment "B"

\begin{tabular}{l|ccc|ccc|ccc} 
& \multicolumn{3}{|c|}{ Shannon diversity index $(\mathrm{H})$} & \multicolumn{3}{|c|}{ Substrate richness (SR) } & \multicolumn{3}{|c}{ Shannon evenness (E) } \\
Months & 1 & 5 & 10 & 1 & 5 & 10 & 1 & 5 \\
\hline LQS & $3,35^{\mathrm{a}}$ & $3,10^{\mathrm{ac}}$ & $2,97^{\mathrm{a}}$ & $29,5^{\mathrm{a}}$ & $26,0^{\mathrm{a}}$ & $22,5^{\mathrm{a}}$ & $0,99^{\mathrm{a}}$ & $0,97^{\mathrm{a}}$ & $0,95^{\mathrm{a}}$ \\
LQS+5\% RMSM & $3,26^{\mathrm{ab}}$ & $2,93^{\mathrm{ab}}$ & $3,20^{\mathrm{b}}$ & $29,5^{\mathrm{a}}$ & $24,5^{\mathrm{a}}$ & $29,0^{\mathrm{b}}$ & $0,98^{\mathrm{ac}}$ & $0,95^{\mathrm{a}}$ & $0,96^{\mathrm{a}}$ \\
LQS+10\% RMSM & $3,21^{\mathrm{ab}}$ & $2,87^{\mathrm{b}}$ & $3,01^{\mathrm{a}}$ & $25,0^{\mathrm{b}}$ & $20,5^{\mathrm{b}}$ & $22,5^{\mathrm{a}}$ & $1,00^{\mathrm{ab}}$ & $0,96^{\mathrm{a}}$ & $0,97^{\mathrm{a}}$ \\
LQS+20\% RMSM & $3,08^{\mathrm{b}}$ & $3,03^{\mathrm{abc}}$ & $3,12^{\mathrm{b}}$ & $21,0^{\mathrm{c}}$ & $21,0^{\mathrm{b}}$ & $24,0^{\mathrm{c}}$ & $1,01^{\mathrm{b}}$ & $0,97^{\mathrm{a}}$ & $0,98^{\mathrm{b}}$ \\
LQS+50\% RMSM & $3,11^{\mathrm{b}}$ & $3,20^{\mathrm{c}}$ & $2,66^{\mathrm{c}}$ & $25,5^{\mathrm{b}}$ & $27,0^{\mathrm{a}}$ & $15,5^{\mathrm{d}}$ & $0,98^{\mathrm{ac}}$ & $0,97^{\mathrm{a}}$ & $0,99^{\mathrm{b}}$ \\
RMSM & $3,07^{\mathrm{b}}$ & $3,15^{\mathrm{c}}$ & $3,12^{\mathrm{b}}$ & $25,0^{\mathrm{b}}$ & $27,0^{\mathrm{a}}$ & $26,5^{\mathrm{e}}$ & $0,96^{\mathrm{c}}$ & $0,96^{\mathrm{a}}$ & $0,96^{\mathrm{a}}$
\end{tabular}


List of Figures and captions:

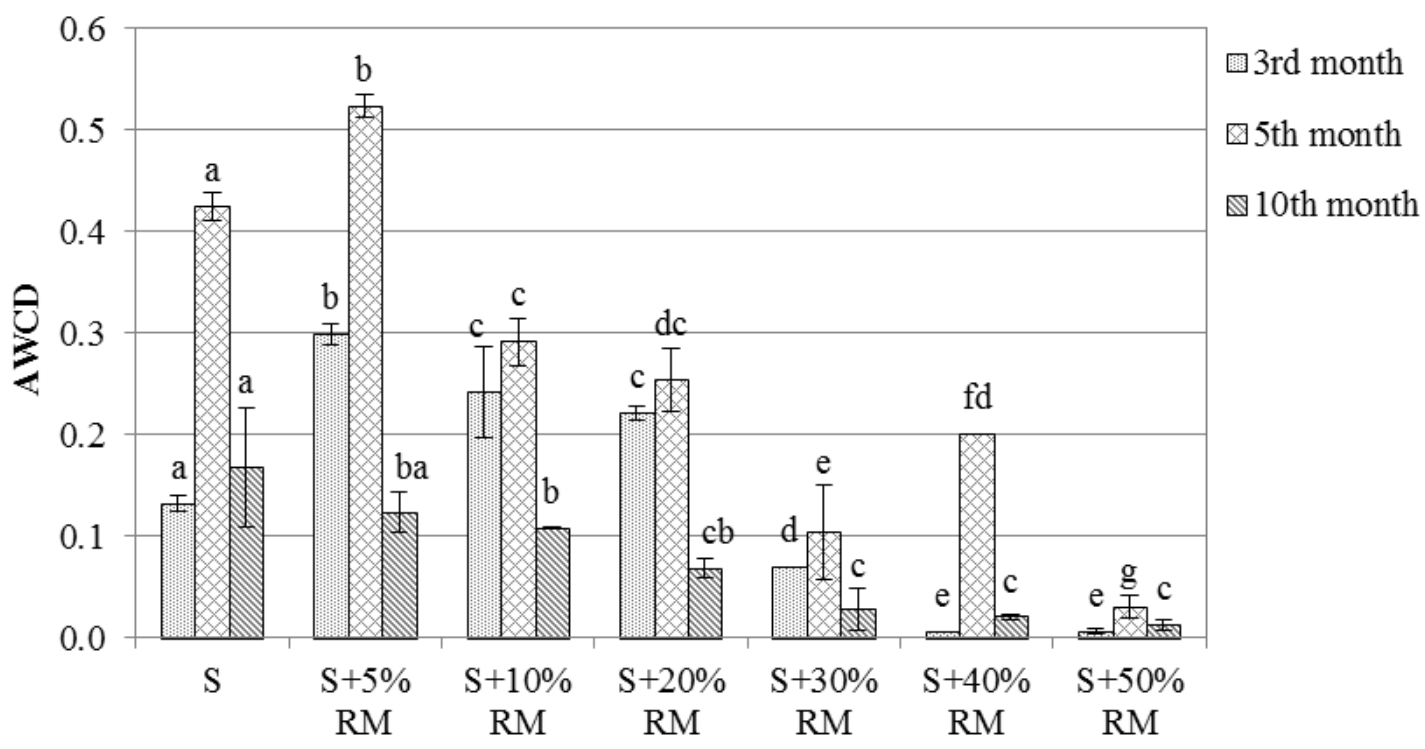

Figure 1. Average well color development (AWCD) at $120 \mathrm{~h}$ during experiment "A" 


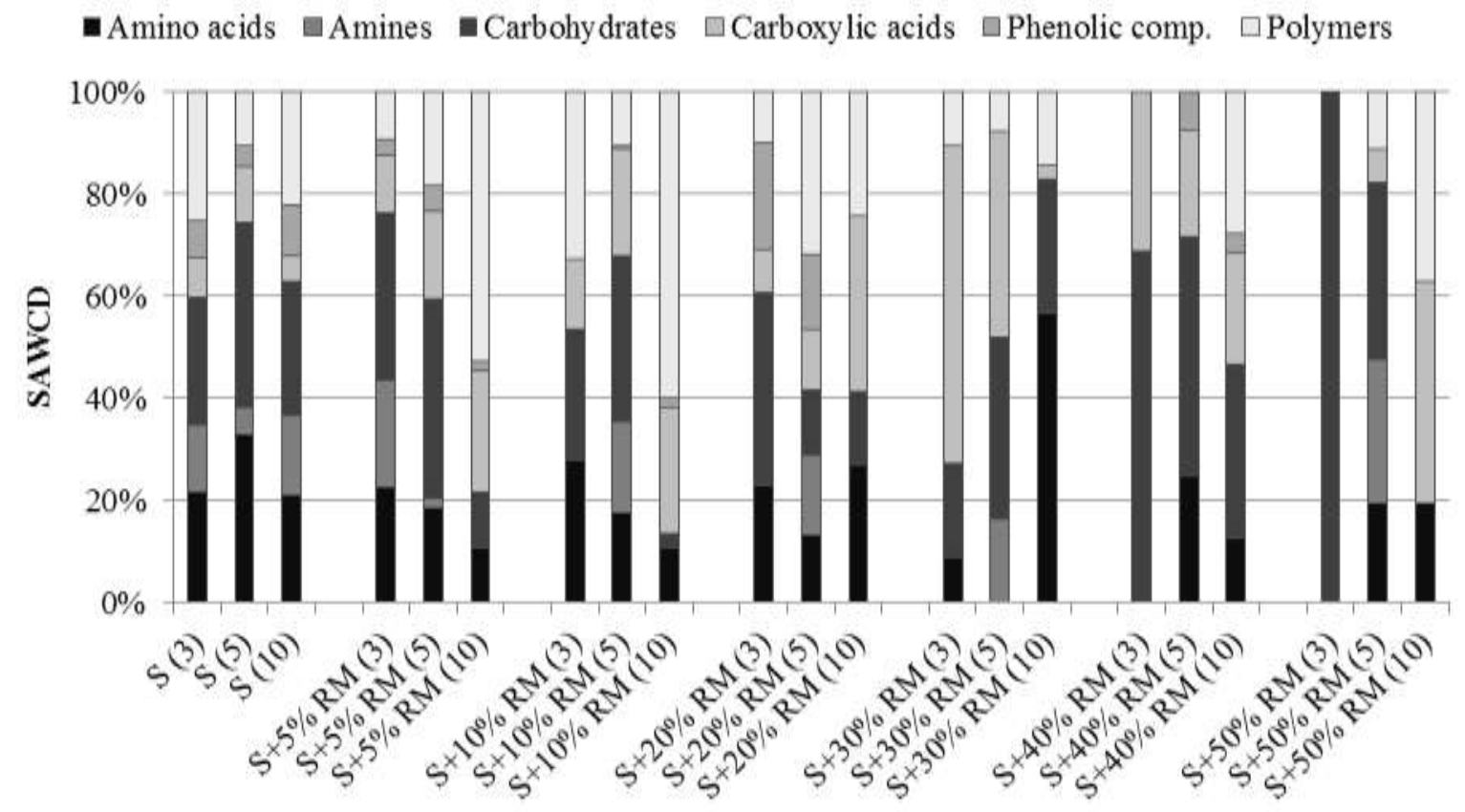

Figure 2. Substrate average well color development (SAWCD) at $120 \mathrm{~h}$ during experiment "A". (Numbers in brackets indicate the sampling month.) 


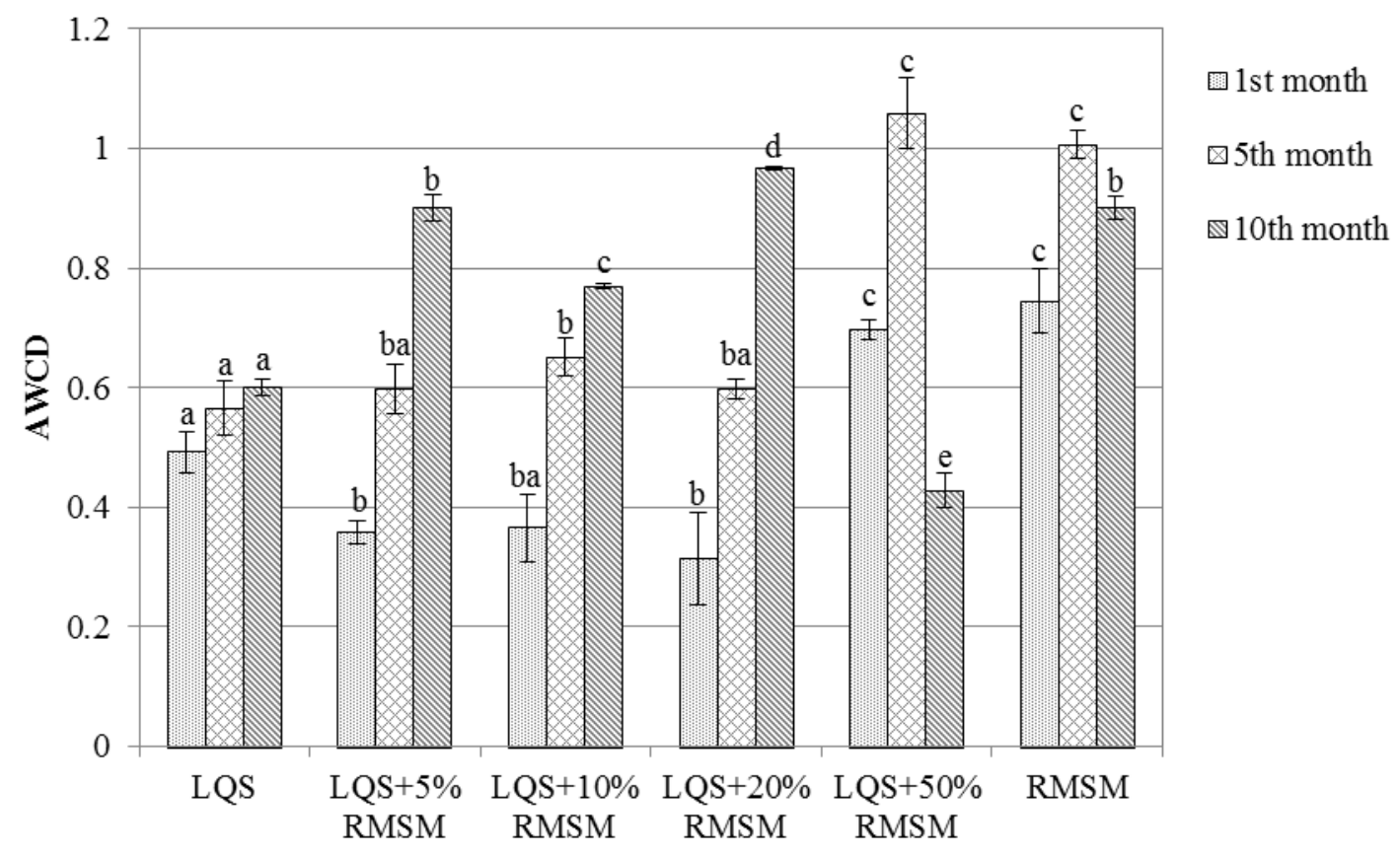

Figure 3. Average well color development (AWCD) at $120 \mathrm{~h}$ during experiment "B" 


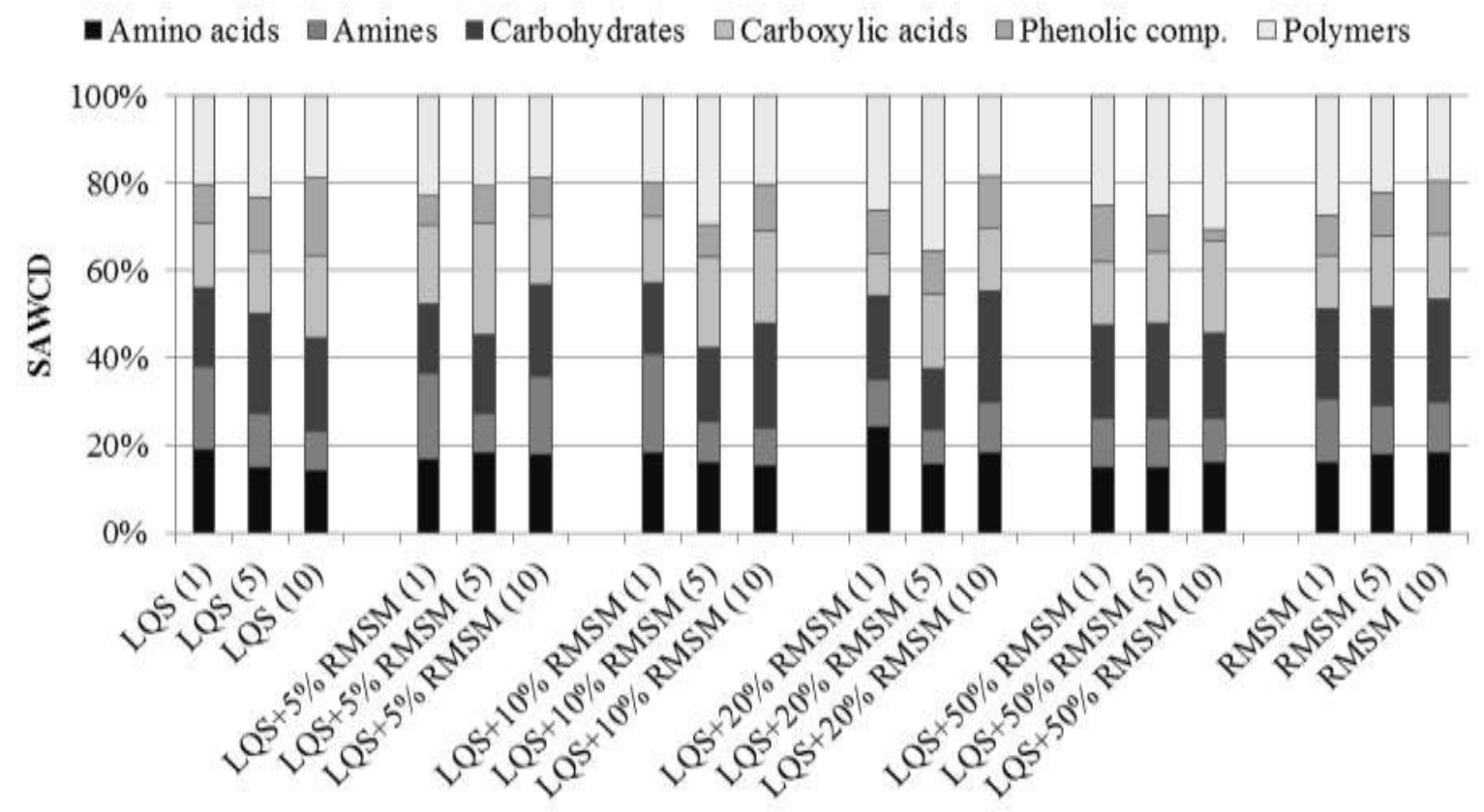

Figure 4. Substrate average well color development (SAWCD) at $120 \mathrm{~h}$ during experiment "B". (Numbers in brackets indicate the sampling month.) 
Supplementary

Table 1. Chemical properties of the soils in experiment " $A$ "*

\begin{tabular}{|c|c|c|c|c|c|c|c|c|c|}
\hline \multirow[b]{2}{*}{ Months } & \multicolumn{3}{|c|}{$\mathrm{pH}$} & \multicolumn{3}{|c|}{$\mathrm{EC}(\mu \mathrm{S} / \mathrm{cm})$} & \multicolumn{3}{|c|}{ Humus (\%) } \\
\hline & 3 & 5 & 10 & 3 & 5 & 10 & 3 & 5 & 10 \\
\hline$S$ & 6.9 & 5.9 & 5.9 & 690 & 1035 & 812 & 0.53 & 0.44 & 0.46 \\
\hline $\mathrm{S}+5 \% \mathrm{RM}$ & 7.4 & 7.4 & 7.5 & 1300 & 1410 & 1530 & 0.44 & 0.45 & 0.44 \\
\hline $\mathrm{S}+10 \% \mathrm{RM}$ & 7.9 & 7.7 & 7.9 & 1871 & 1851 & 1764 & 0.45 & 0.40 & 0.43 \\
\hline $\mathrm{S}+20 \% \mathrm{RM}$ & 8.2 & 8.1 & 8.0 & 2830 & 2530 & 2540 & 0.65 & 0.58 & 0.59 \\
\hline S+30\% RM & 8.4 & 8.3 & 8.4 & 3180 & 3090 & 3390 & 0.47 & 0.38 & 0.38 \\
\hline $\mathrm{S}+40 \% \mathrm{RM}$ & 8.6 & 8.3 & 8.5 & 4430 & 3830 & 4560 & 0.38 & 0.33 & 0.36 \\
\hline \multirow{2}{*}{$\mathrm{S}+50 \% \mathrm{RM}$} & 8.6 & 8.5 & 8.5 & 5600 & 5140 & 5820 & 0.39 & 0.31 & 0.34 \\
\hline & \multicolumn{3}{|c|}{$\mathrm{NH}_{4}{ }^{+}-\mathrm{N}(\mathrm{mg} / \mathrm{kg})$} & \multicolumn{3}{|c|}{$\mathrm{NO}_{3}^{-}-\mathrm{N}(\mathrm{mg} / \mathrm{kg})$} & \multicolumn{3}{|c|}{ Total N (\%) } \\
\hline Months & 3 & 5 & 10 & 3 & 5 & 10 & 3 & 5 & 10 \\
\hline S & 33.05 & 42.87 & 29.38 & 94.3 & 106 & 89.0 & 0.041 & 0.038 & 0.050 \\
\hline $\mathrm{S}+5 \% \mathrm{RM}$ & 10.34 & 8.62 & 10.65 & 97.5 & 104 & 109 & 0.038 & 0.045 & 0.037 \\
\hline $\mathrm{S}+10 \% \mathrm{RM}$ & 7.39 & 8.62 & 7.87 & 115 & 114 & 87.9 & 0.034 & 0.031 & 0.037 \\
\hline $\mathrm{S}+20 \% \mathrm{RM}$ & 4.43 & 5.13 & 9.72 & 70.4 & 64.3 & 71.7 & 0.034 & 0.034 & 0.037 \\
\hline $\mathrm{S}+30 \% \mathrm{RM}$ & 3.94 & 3.83 & 4.63 & 69.9 & 68.0 & 73.1 & 0.024 & 0.028 & 0.037 \\
\hline $\mathrm{S}+40 \% \mathrm{RM}$ & 2.46 & 2.39 & 7.14 & 44.3 & 40.7 & 55.7 & 0.017 & 0.021 & 0.023 \\
\hline $\mathrm{S}+50 \% \mathrm{RM}$ & 2.09 & 2.54 & 3.33 & 18.3 & 25.4 & 29.5 & 0.014 & 0.014 & 0.017 \\
\hline
\end{tabular}

Table 2. Correlation analysis for AWCD in experiment " $\mathrm{A}$ "

\begin{tabular}{lccc} 
& \multicolumn{3}{c}{ AWCD } \\
& $3^{\text {rd }}$ month & $5^{\text {th }}$ month & $10^{\text {th }}$ month \\
\hline SAWCD amino acids & $\mathbf{0 . 9 6 5 0}$ & $\mathbf{0 . 8 6 2 6}$ & $\mathbf{0 . 8 2 3 3}$ \\
SAWCD amines & 0.5883 & 0.0869 & $\mathbf{0 . 7 0 0 0}$ \\
SAWCD carbohydrates & $\mathbf{0 . 9 7 0 8}$ & $\mathbf{0 . 9 5 5 2}$ & $\mathbf{0 . 7 6 5 5}$ \\
SAWCD carboxylic acids & 0.2908 & $\mathbf{0 . 7 8 3 1}$ & 0.3853 \\
SAWCD phenolic comp. & 0.4672 & 0.3508 & $\mathbf{0 . 7 5 7 5}$ \\
SAWCD polymers & $\mathbf{0 . 6 4 3 2}$ & 0.5483 & $\mathbf{0 . 6 2 5 8}$ \\
Shannon diversity (H) & 0.5475 & $\mathbf{0 . 8 5 7 9}$ & $\mathbf{0 . 7 9 3 5}$ \\
Substrate richness (SR) & $\mathbf{0 . 8 9 7 8}$ & $\mathbf{0 . 9 2 9 4}$ & $\mathbf{0 . 9 5 0 3}$ \\
Shannon evenness (E) & 0.4456 & 0.4256 & 0.1938 \\
RM\% & $\mathbf{- 0 . 8 0 0 8}$ & $\mathbf{- 0 . 8 8 6 6}$ & $\mathbf{- 0 . 9 0 8 9}$ \\
pH & -0.3552 & $\mathbf{- 0 . 7 3 8 6}$ & $\mathbf{- 0 . 8 8 5 1}$ \\
EC & $\mathbf{- 0 . 7 5 4 4}$ & $\mathbf{- 0 . 8 8 2 8}$ & $\mathbf{- 0 . 8 8 5 6}$ \\
Humus & 0.4615 & 0.4906 & 0.4353 \\
$\mathrm{NH}_{4}{ }^{+}-\mathrm{N}$ & 0.2111 & 0.5413 & $\mathbf{0 . 7 8 3 9}$ \\
$\mathrm{NO}_{3}{ }^{-} \mathrm{N}$ & $\mathbf{0 . 8 0 6 8}$ & $\mathbf{0 . 7 9 7 7}$ & $\mathbf{0 . 7 5 9 2}$ \\
Total N & $\mathbf{0 . 8 2 3 2}$ & $\mathbf{0 . 9 0 4 3}$ & $\mathbf{0 . 7 9 0 4}$
\end{tabular}


Table 3: Substrate average well color development (SAWCD) at $120 \mathrm{~h}$ during experiment "A"

\begin{tabular}{|c|c|c|c|c|c|c|c|c|c|}
\hline SAWCD & \multicolumn{3}{|c|}{ Amino acids } & \multicolumn{3}{|c|}{ Amines } & \multicolumn{3}{|c|}{ Carbohydrates } \\
\hline Months & 3 & 5 & 10 & 3 & 5 & 10 & 3 & 5 & 10 \\
\hline S & $0.15^{\mathrm{a}}$ & $0.61^{\mathrm{a}}$ & $0.17^{\mathrm{a}}$ & $0.09^{\mathrm{a}}$ & $0.10^{\mathrm{a}}$ & $0.12^{\mathrm{a}}$ & $0.17^{\mathrm{a}}$ & $0.67^{\mathrm{a}}$ & $0.21^{\mathrm{a}}$ \\
\hline $\mathrm{S}+5 \% \mathrm{RM}$ & $0.32^{\mathrm{b}}$ & $0.43^{\mathrm{b}}$ & $0.06^{\mathrm{b}}$ & $0.30^{\mathrm{b}}$ & $0.05^{\mathrm{a}}$ & $0.00^{\mathrm{b}}$ & $0.47^{\text {ba }}$ & $0.91^{\mathrm{b}}$ & $0.07^{\mathrm{b}}$ \\
\hline S+10\% RM & $0.30^{\mathrm{b}}$ & $0.21^{\mathrm{c}}$ & $0.08^{\mathrm{b}}$ & $0.00^{\mathrm{c}}$ & $0.21^{\mathrm{b}}$ & $0.00^{\mathrm{b}}$ & $0.28^{\mathrm{c}}$ & $0.40^{\mathrm{c}}$ & $0.02^{\mathrm{bc}}$ \\
\hline $\mathrm{S}+20 \% \mathrm{RM}$ & $0.18^{\mathrm{c}}$ & $0.24^{\mathrm{c}}$ & $0.12^{\mathrm{ba}}$ & $0.00^{\mathrm{c}}$ & $0.28^{\mathrm{c}}$ & $0.00^{\mathrm{b}}$ & $0.29^{\mathrm{db}}$ & $0.23^{\mathrm{d}}$ & $0.06^{\mathrm{bc}}$ \\
\hline S+30\% RM & $0.04^{\mathrm{d}}$ & $0.00^{\mathrm{d}}$ & $0.04^{\mathrm{b}}$ & $0.00^{\mathrm{c}}$ & $0.10^{\mathrm{a}}$ & $0.00^{\mathrm{b}}$ & $0.08^{\mathrm{de}}$ & $0.21^{\mathrm{d}}$ & $0.02^{\mathrm{bc}}$ \\
\hline $\mathrm{S}+40 \% \mathrm{RM}$ & $0.00^{\mathrm{e}}$ & $0.17^{\mathrm{c}}$ & $0.02^{\mathrm{b}}$ & $0.00^{\mathrm{c}}$ & $0.00^{\mathrm{d}}$ & $0.00^{\mathrm{b}}$ & $0.01^{\mathrm{e}}$ & $0.31^{\mathrm{e}}$ & $0.05^{\mathrm{bc}}$ \\
\hline \multirow[t]{2}{*}{$\mathrm{S}+50 \% \mathrm{RM}$} & $0.00^{\mathrm{e}}$ & $0.03^{\mathrm{d}}$ & $0.02^{\mathrm{b}}$ & $0.00^{\mathrm{c}}$ & $0.04^{\mathrm{a}}$ & $0.00^{\mathrm{b}}$ & $0.01^{\mathrm{e}}$ & $0.04^{\mathrm{f}}$ & $0.00^{\mathrm{c}}$ \\
\hline & \multicolumn{3}{|c|}{ Carboxylic acids } & \multicolumn{3}{|c|}{ Phenolic compounds } & \multicolumn{3}{|c|}{ Polymers } \\
\hline Months & 3 & 5 & 10 & 3 & 5 & 10 & 3 & 5 & 10 \\
\hline S & $0.05^{\mathrm{a}}$ & $0.21^{\mathrm{ad}}$ & $0.04^{\mathrm{ac}}$ & $0.05^{\mathrm{a}}$ & $0.07^{\mathrm{a}}$ & $0.08^{\mathrm{a}}$ & $0.17^{\mathrm{a}}$ & $0.20^{\mathrm{a}}$ & $0.17^{\mathrm{a}}$ \\
\hline $\mathrm{S}+5 \% \mathrm{RM}$ & $0.16^{\mathrm{a}}$ & $0.40^{\mathrm{b}}$ & $0.14^{\mathrm{b}}$ & $0.04^{\mathrm{a}}$ & $0.12^{\mathrm{a}}$ & $0.01^{\mathrm{b}}$ & $0.13^{\text {ba }}$ & $0.43^{\mathrm{b}}$ & $0.32^{\mathrm{b}}$ \\
\hline $\mathrm{S}+10 \% \mathrm{RM}$ & $0.15^{\mathrm{a}}$ & $0.25^{\mathrm{cd}}$ & $0.18^{\mathrm{b}}$ & $0.00^{\mathrm{b}}$ & $0.00^{\mathrm{a}}$ & $0.01^{\mathrm{b}}$ & $0.36^{\mathrm{c}}$ & $0.13^{\mathrm{a}}$ & $0.43^{\mathrm{c}}$ \\
\hline $\mathrm{S}+20 \% \mathrm{RM}$ & $0.07^{\mathrm{a}}$ & $0.22^{\mathrm{d}}$ & $0.15^{\mathrm{b}}$ & $0.17^{\mathrm{c}}$ & $0.27^{\mathrm{a}}$ & $0.00^{\mathrm{b}}$ & $0.08^{\mathrm{db}}$ & $0.58^{\mathrm{b}}$ & $0.11^{\mathrm{d}}$ \\
\hline $\mathrm{S}+30 \% \mathrm{RM}$ & $0.29^{\mathrm{b}}$ & $0.24^{\mathrm{d}}$ & $0.00^{\mathrm{c}}$ & $0.00^{\mathrm{b}}$ & $0.00^{\mathrm{a}}$ & $0.00^{\mathrm{b}}$ & $0.05^{\text {ed }}$ & $0.05^{\mathrm{a}}$ & $0.01^{\mathrm{e}}$ \\
\hline $\mathrm{S}+40 \% \mathrm{RM}$ & $0.00^{\mathrm{a}}$ & $0.14^{\mathrm{e}}$ & $0.03^{\mathrm{c}}$ & $0.00^{\mathrm{b}}$ & $0.05^{\mathrm{a}}$ & $0.01^{\mathrm{b}}$ & $0.00^{\mathrm{e}}$ & $0.00^{\mathrm{a}}$ & $0.04^{\mathrm{e}}$ \\
\hline $\mathrm{S}+50 \% \mathrm{RM}$ & $0.00^{\mathrm{a}}$ & $0.01^{\mathrm{f}}$ & $0.04^{\mathrm{c}}$ & $0.00^{\mathrm{b}}$ & $0.00^{\mathrm{a}}$ & $0.00^{\mathrm{b}}$ & $0.00^{\mathrm{e}}$ & $0.01^{\mathrm{a}}$ & $0.04^{\mathrm{e}}$ \\
\hline
\end{tabular}

Table 4. Correlation analysis for $\mathrm{H}, \mathrm{SR}$ and $\mathrm{E}$ in experiment "A"

\begin{tabular}{|c|c|c|c|c|c|c|c|c|c|}
\hline & \multicolumn{3}{|c|}{ Shannon diversity $(\mathrm{H})$} & \multicolumn{3}{|c|}{ Substrate richness (SR) } & \multicolumn{3}{|c|}{ Shannon evenness (E) } \\
\hline & $\begin{array}{c}3^{\text {rd }} \\
\text { month }\end{array}$ & $\begin{array}{c}5^{\text {th }} \\
\text { month }\end{array}$ & $\begin{array}{c}10^{\text {th }} \\
\text { month }\end{array}$ & $\begin{array}{c}3^{\text {rd }} \\
\text { month }\end{array}$ & $\begin{array}{c}5^{\text {th }} \\
\text { month }\end{array}$ & $\begin{array}{c}10^{\text {th }} \\
\text { month }\end{array}$ & $\begin{array}{c}3^{\text {rd }} \\
\text { month }\end{array}$ & $\begin{array}{c}5^{\text {th }} \\
\text { month }\end{array}$ & $\begin{array}{l}10^{\text {th }} \\
\text { month }\end{array}$ \\
\hline & \multicolumn{3}{|c|}{$\mathrm{r}$} & \multicolumn{3}{|c|}{$\mathrm{r}$} & \multicolumn{3}{|c|}{$\mathrm{r}$} \\
\hline RM\% & -0.7478 & -0.8038 & -0.6289 & -0.9322 & -0.9148 & -0.8539 & -0.5609 & -0.5401 & -0.2173 \\
\hline $\mathrm{pH}$ & -0.7493 & -0.5898 & -0.8478 & -0.6421 & -0.7170 & -0.9408 & -0.3238 & -0.2288 & -0.1281 \\
\hline EC & -0.7317 & -0.7858 & -0.5935 & -0.8909 & -0.9093 & -0.8442 & -0.6222 & -0.6384 & -0.2177 \\
\hline Humus & 0.4869 & 0.6083 & 0.2045 & 0.6277 & 0.4931 & 0.5111 & 0.5021 & 0.4189 & 0.1558 \\
\hline $\mathrm{NH}_{4}{ }^{+}-\mathrm{N}$ & 0.6889 & 0.4231 & 0.8480 & 0.5475 & 0.5417 & 0.9088 & 0.2766 & 0.1498 & 0.2293 \\
\hline $\mathrm{NO}_{3}{ }^{-}-\mathrm{N}$ & 0.5438 & 0.7977 & 0.4112 & 0.8647 & 0.8716 & 0.6613 & 0.6135 & 0.5395 & 0.2587 \\
\hline Total N & 0.7698 & 0.7574 & 0.5662 & 0.9661 & 0.8349 & 0.8195 & 0.5773 & 0.5924 & 0.0567 \\
\hline
\end{tabular}


Table 5. Chemical properties of the soils in experiment "B"*

\begin{tabular}{|c|c|c|c|c|c|c|c|c|c|}
\hline \multirow[b]{2}{*}{ Months } & \multicolumn{3}{|c|}{$\mathrm{pH}$} & \multicolumn{3}{|c|}{$\mathrm{EC}(\mu \mathrm{S} / \mathrm{cm})$} & \multicolumn{3}{|c|}{ Humus (\%) } \\
\hline & 1 & 5 & 10 & 1 & 5 & 10 & 1 & 5 & 10 \\
\hline LQS & 8.0 & 7.7 & 7.8 & 1161 & 1371 & 1051 & 1.27 & 1.17 & 1.38 \\
\hline LQS+5\% RMSM & 8.2 & 8.1 & 8.0 & 1439 & 1353 & 1064 & 1.22 & 1.32 & 1.31 \\
\hline LQS+10\% RMSM & 8.2 & 8.2 & 8.0 & 1311 & 1293 & 1295 & 1.68 & 1.68 & 1.76 \\
\hline LQS+20\% RMSM & 8.1 & 8.2 & 8.1 & 1709 & 1236 & 1370 & 1.76 & 1.98 & 1.93 \\
\hline LQS+50\% RMSM & 8.3 & 8.2 & 8.1 & 1458 & 1272 & 1140 & 2.12 & 2.28 & 2.14 \\
\hline \multirow{2}{*}{ RMSM } & 8.7 & 8.5 & 8.1 & 1567 & 972 & 1157 & 2.82 & 3.08 & 3.15 \\
\hline & \multicolumn{3}{|c|}{$\mathrm{NH}_{4}{ }^{+}-\mathrm{N}(\mathrm{mg} / \mathrm{kg})$} & \multicolumn{3}{|c|}{$\mathrm{NO}_{3}{ }^{-}-\mathrm{N}(\mathrm{mg} / \mathrm{kg})$} & \multicolumn{3}{|c|}{ Total N (\%) } \\
\hline Months & 1 & 5 & 10 & 1 & 5 & 10 & 1 & 5 & 10 \\
\hline LQS & 8.93 & 6.17 & 10.12 & 2.38 & 1.85 & 1.79 & 0.070 & 0.067 & 0.077 \\
\hline LQS+5\% RMSM & 8.02 & 4.60 & 9.77 & 4.94 & 4.02 & 1.15 & 0.057 & 0.067 & 0.060 \\
\hline LQS+10\% RMSM & 6.06 & 4.60 & 7.22 & 14.39 & 4.02 & 1.11 & 0.093 & 0.083 & 0.093 \\
\hline LQS+20\% RMSM & 7.78 & 5.17 & 9.52 & 7.78 & 2.30 & 1.19 & 0.090 & 0.103 & 0.077 \\
\hline LQS+50\% RMSM & 7.22 & 6.11 & 10.92 & 18.33 & 6.11 & 1.72 & 0.113 & 0.130 & 0.100 \\
\hline RMSM & 9.37 & 5.91 & 10.41 & 40.09 & 9.14 & 5.21 & 0.160 & 0.180 & 0.173 \\
\hline
\end{tabular}

* Standard deviation max. $10 \%(n=3)$

Table 6. Correlation analysis for AWCD in experiment "B"

\begin{tabular}{lccc} 
& \multicolumn{3}{c}{ AWCD } \\
& $1^{\text {st }}$ month & $5^{\text {th }}$ month & $10^{\text {th }}$ month \\
\hline SAWCD amino acids & $\mathbf{0 . 6 7 4 4}$ & $\mathbf{0 . 9 5 9 8}$ & $\mathbf{0 . 9 6 5 2}$ \\
SAWCD amines & 0.5448 & $\mathbf{0 . 8 8 5 9}$ & $\mathbf{0 . 7 5 6 2}$ \\
SAWCD carbohydrates & $\mathbf{0 . 9 8 0 5}$ & $\mathbf{0 . 9 5 6 7}$ & $\mathbf{0 . 9 6 6 6}$ \\
SAWCD carboxylic acids & $\mathbf{0 . 8 4 4 1}$ & $\mathbf{0 . 7 4 1 4}$ & $\mathbf{0 . 6 9 1 9}$ \\
SAWCD phenolic comp. & $\mathbf{0 . 8 4 0 3}$ & $\mathbf{0 . 8 4 7 1}$ & $\mathbf{0 . 7 1 7 4}$ \\
SAWCD polymers & $\mathbf{0 . 9 5 2 0}$ & $\mathbf{0 . 7 2 3 0}$ & $\mathbf{0 . 7 6 8 4}$ \\
Shannon diversity (H) & -0.3645 & $\mathbf{0 . 6 0 9 8}$ & $\mathbf{0 . 9 2 3 8}$ \\
Substrate richness (SR) & 0.1028 & $\mathbf{0 . 6 0 2 5}$ & $\mathbf{0 . 8 4 8 5}$ \\
Shannon evenness (E) & $\mathbf{- 0 . 7 8 9 3}$ & 0.0155 & -0.4374 \\
RMSM\% & $\mathbf{0 . 8 0 9 8}$ & $\mathbf{0 . 8 7 8 6}$ & 0.0542 \\
pH & $\mathbf{0 . 6 1 7 9}$ & $\mathbf{0 . 6 0 6 5}$ & 0.2848 \\
EC & 0.0072 & $\mathbf{- 0 . 6 6 2 8}$ & 0.4069 \\
Humus & $\mathbf{0 . 7 4 2 2}$ & $\mathbf{0 . 8 4 5 6}$ & 0.1444 \\
$\mathrm{NH}_{4}{ }^{+}-\mathrm{N}$ & 0.3987 & 0.5354 & -0.3079 \\
$\mathrm{NO}_{3}{ }^{-} \mathrm{N}$ & $\mathbf{0 . 7 3 9 4}$ & $\mathbf{0 . 8 8 4 5}$ & 0.1692 \\
Total N & $\mathbf{0 . 7 5 4 3}$ & $\mathbf{0 . 8 7 2 5}$ & 0.0835
\end{tabular}


Table 7: Substrate average well color development (SAWCD) at $120 \mathrm{~h}$ during experiment "B"

\begin{tabular}{l|ccc|ccc|ccc} 
SAWCD & \multicolumn{3}{|c|}{ Amino acids } & \multicolumn{3}{c|}{ Amines } & \multicolumn{3}{c}{ Carbohydrates } \\
Months & 1 & 5 & 10 & 1 & 5 & 10 & 1 & 5 & 10 \\
\hline LQS & $0.54^{\text {ab }}$ & $0.41^{\mathrm{a}}$ & $0.48^{\mathrm{ae}}$ & $0.54^{\mathrm{a}}$ & $0.34^{\mathrm{a}}$ & $0.29^{\mathrm{a}}$ & $0.51^{\mathrm{a}}$ & $0.63^{\mathrm{a}}$ & $0.71^{\mathrm{a}}$ \\
LQS+5\% RMSM & $0.36^{\mathrm{a}}$ & $0.58^{\mathrm{b}}$ & $0.93^{\mathrm{bd}}$ & $0.42^{\mathrm{a}}$ & $0.28^{\mathrm{a}}$ & $0.92^{\mathrm{a}}$ & $0.34^{\mathrm{a}}$ & $0.56^{\mathrm{a}}$ & $1.08^{\mathrm{b}}$ \\
LQS+10\% RMSM & $0.40^{\mathrm{ab}}$ & $0.55^{\mathrm{b}}$ & $0.68^{\mathrm{c}}$ & $0.49^{\mathrm{a}}$ & $0.32^{\mathrm{a}}$ & $0.37^{\mathrm{a}}$ & $0.35^{\mathrm{a}}$ & $0.59^{\mathrm{a}}$ & $1.06^{\mathrm{b}}$ \\
LQS+20\% RMSM & $0.49^{\mathrm{ab}}$ & $0.56^{\mathrm{b}}$ & $0.95^{\mathrm{d}}$ & $0.22^{\mathrm{b}}$ & $0.28^{\mathrm{a}}$ & $0.61^{\mathrm{a}}$ & $0.38^{\mathrm{a}}$ & $0.51^{\mathrm{a}}$ & $1.33^{\mathrm{c}}$ \\
LQS+50\% RMSM & $0.59^{\mathrm{ab}}$ & $0.93^{\mathrm{c}}$ & $0.39^{\mathrm{e}}$ & $0.43^{\mathrm{a}}$ & $0.68^{\mathrm{b}}$ & $0.25^{\mathrm{a}}$ & $0.84^{\mathrm{b}}$ & $1.33^{\mathrm{b}}$ & $0.47^{\mathrm{d}}$ \\
RMSM & $0.65^{\mathrm{b}}$ & $0.95^{\mathrm{c}}$ & $0.88^{\mathrm{d}}$ & $0.57^{\mathrm{a}}$ & $0.59^{\mathrm{b}}$ & $0.56^{\mathrm{a}}$ & $0.83^{\mathrm{b}}$ & $1.21^{\mathrm{b}}$ & $1.13^{\mathrm{b}}$ \\
\hline & \multicolumn{3}{|c|}{ Carboxylic acids } & \multicolumn{2}{c|}{ Phenolic compounds } & \multicolumn{3}{c}{ Polymers } \\
Months & 1 & 5 & 10 & 1 & 5 & 10 & 1 & 5 & 10 \\
\hline LQS & $0.43^{\mathrm{abcef}}$ & $0.39^{\mathrm{ac}}$ & $0.63^{\mathrm{a}}$ & $0.25^{\mathrm{ac}}$ & $0.34^{\mathrm{ab}}$ & $0.58^{\mathrm{a}}$ & $0.57^{\mathrm{a}}$ & $0.64^{\mathrm{a}}$ & $0.63^{\mathrm{ac}}$ \\
LQS+5\% RMSM & $0.39^{\mathrm{bcf}}$ & $0.82^{\mathrm{bcd}}$ & $0.81^{\mathrm{bd}}$ & $0.14^{\mathrm{bc}}$ & $0.26^{\mathrm{b}}$ & $0.46^{\mathrm{a}}$ & $0.49^{\mathrm{a}}$ & $0.65^{\mathrm{a}}$ & $0.96^{\mathrm{b}}$ \\
LQS+10\% RMSM & $0.33^{\mathrm{cd}}$ & $0.71^{\mathrm{bcd}}$ & $0.92^{\mathrm{c}}$ & $0.17^{\mathrm{bc}}$ & $0.26^{\mathrm{b}}$ & $0.48^{\mathrm{a}}$ & $0.43^{\mathrm{a}}$ & $1.01^{\mathrm{be}}$ & $0.89^{\mathrm{bc}}$ \\
LQS+20\% RMSM & $0.20^{\mathrm{d}}$ & $0.62^{\mathrm{c}}$ & $0.76^{\mathrm{df}}$ & $0.21^{\mathrm{c}}$ & $0.36^{\mathrm{a}}$ & $0.60^{\mathrm{a}}$ & $0.53^{\mathrm{a}}$ & $1.27^{\mathrm{ce}}$ & $0.97^{\mathrm{b}}$ \\
LQS+50\% RMSM & $0.56^{\text {ef }}$ & $1.01^{\mathrm{d}}$ & $0.51^{\mathrm{e}}$ & $0.50^{\mathrm{d}}$ & $0.51^{\mathrm{d}}$ & $0.06^{\mathrm{b}}$ & $0.97^{\mathrm{b}}$ & $1.68^{\mathrm{d}}$ & $0.75^{\mathrm{c}}$ \\
RMSM & $0.48^{\mathrm{f}}$ & $0.86^{\mathrm{bcd}}$ & $0.72^{\mathrm{f}}$ & $0.36^{\mathrm{e}}$ & $0.52^{\mathrm{d}}$ & $0.58^{\mathrm{a}}$ & $1.08^{\mathrm{b}}$ & $1.18^{\mathrm{e}}$ & $0.94^{\mathrm{b}}$
\end{tabular}

Table 8. Correlation analysis for $\mathrm{H}, \mathrm{SR}$ and $\mathrm{E}$ in experiment " $\mathrm{B}$ "

\begin{tabular}{|c|c|c|c|c|c|c|c|c|c|}
\hline & \multicolumn{3}{|c|}{ Shannon diversity $(\mathrm{H})$} & \multicolumn{3}{|c|}{ Substrate richness (SR) } & \multicolumn{3}{|c|}{ Shannon evenness (E) } \\
\hline & $\begin{array}{c}1^{\text {st }} \\
\text { month }\end{array}$ & $\begin{array}{c}5^{\text {th }} \\
\text { month }\end{array}$ & $\begin{array}{c}10^{\text {th }} \\
\text { month }\end{array}$ & $\begin{array}{c}1^{\text {st }} \\
\text { month }\end{array}$ & $\begin{array}{c}5^{\text {th }} \\
\text { month }\end{array}$ & $\begin{array}{l}10^{\text {th }} \\
\text { month }\end{array}$ & $\begin{array}{c}1^{\text {st }} \\
\text { month }\end{array}$ & $\begin{array}{c}5^{\text {th }} \\
\text { month }\end{array}$ & $\begin{array}{l}10^{\text {th }} \\
\text { month }\end{array}$ \\
\hline & & $\mathrm{r}$ & & & $\mathrm{r}$ & & & $\mathrm{r}$ & \\
\hline RMSM\% & -0.6254 & 0.5757 & -0.0477 & -0.3116 & 0.5193 & -0.0472 & -0.6661 & -0.1263 & 0.0616 \\
\hline $\mathrm{pH}$ & -0.5193 & 0.2559 & 0.1397 & -0.2256 & 0.2893 & -0.0223 & -0.6309 & 0.1125 & 0.3583 \\
\hline EC & -0.6861 & -0.4137 & 0.0923 & -0.7287 & -0.2747 & -0.0976 & 0.0729 & 0.2160 & 0.3502 \\
\hline Humus & -0.6840 & 0.5000 & -0.0145 & -0.4715 & 0.3240 & -0.0461 & -0.5229 & -0.0691 & 0.0555 \\
\hline $\mathrm{NH}_{4}{ }^{+}-\mathrm{N}$ & 0.0823 & 0.8046 & -0.2055 & 0.2554 & 0.7462 & -0.1810 & -0.4577 & 0.4912 & 0.1427 \\
\hline $\mathrm{NO}_{3}{ }^{-}-\mathrm{N}$ & -0.5538 & 0.4095 & 0.2144 & -0.2983 & 0.5307 & 0.1526 & -0.6466 & -0.3262 & -0.3452 \\
\hline Total N & -0.6291 & 0.5782 & -0.0123 & -0.4367 & 0.4342 & 0.0123 & -0.5251 & -0.0390 & -0.1484 \\
\hline
\end{tabular}

